Mississippi College School of Law

MC Law Digital Commons

Journal Articles

Faculty Publications

2013

\title{
Beyond Abortion: Why the Personhood Movement Implicates Reproductive Choice
}

Jonathan Will

Mississippi College School of Law, jwill@mc.edu

Follow this and additional works at: http://dc.law.mc.edu/faculty-journals

Part of the Health Law and Policy Commons

\section{Recommended Citation}

39 Am. J. of L. \& Med. 573 (2013).

This Article is brought to you for free and open access by the Faculty Publications at MC Law Digital Commons. It has been accepted for inclusion in Journal Articles by an authorized administrator of MC Law Digital Commons. 


\title{
Beyond Abortion: Why the Personhood Movement Implicates Reproductive Choice
}

\author{
Jonathan F. Will ${ }^{\dagger}$
}

\begin{tabular}{|c|c|}
\hline & \\
\hline I. & INTRODUCTION ....................... \\
\hline & PERSONHOOD MOVEMENT .. \\
\hline & 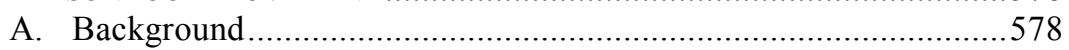 \\
\hline & B. Personhood Goes to Mississippi... \\
\hline III. & PERSONHOOD ...................... \\
\hline & A. Imme \\
\hline & B. Treatment of Pregnant Women and Miscarriages ................................ \\
\hline & C. Implications for Contraception and/or In Vitro Fertilization......... \\
\hline & NEW LANGUAGE-SAME CONCERNS REGARDING REPRODUCTIVE \\
\hline & СHOICE \\
\hline & A. Personhood al \\
\hline & B. Personho \\
\hline & .......602 \\
\hline & 2. Preimplantation Genetic $\mathrm{S}$ \\
\hline & 3. Transfer, Selective Reduction, and Disposition of Unused \\
\hline & .....610 \\
\hline & \\
\hline
\end{tabular}

In 2008, an amendment was proposed to the Colorado Constitution that sought to attach the rights and protections associated with legal "personhood" to any human being from the moment of fertilization. Although the initiative was defeated, it sparked a nation-wide Personhood Movement that has spurred similar efforts at the federal level and in over a dozen states. Personhood advocates choose terms like

\footnotetext{
† Associate Professor of Law and Director of the Bioethics \& Health Law Center, Mississippi College School of Law. Special thanks to Dr. Eli Y. Adashi, John P. Anderson, Anne Bloom, Caitlin E. Borgmann, Khiara M. Bridges, I. Glenn Cohen, Stephen Crampton, John D. Haskell, Rebecca Kiessling, Mark Modak-Truran, Cynthia Nicoletti, Dr. Eric A. Pennock, Elizabeth Sepper, Tommy Smith, and an anonymous reviewer for many discussions and/or comments, all of which vastly improved this paper. Helpful research assistance was provided by Katy Taylor Gerber and Justin Warren. This work would not have been possible without the constant support of my family and Mississippi College School of Law. Any errors are my own.
} 
"fertilization," or phrases such as "human being at any stage of development," to identify the "person"-defining moment in the reproductive process, and these designations have profound implications for reproductive choice. Proponents are outspoken in their desire to outlaw abortion, but they are less transparent about their intent with respect to other aspects of reproductive choice, such as contraception and infertility treatments.

This paper describes the background of the Personhood Movement and its attempt to achieve legal protection of the preborn from the earliest moments of biological development. Following the late 2011 failure of the personhood measure in Mississippi, the language used within the Movement was dramatically changed in an attempt to address some of the concerns raised regarding implications for reproductive choice. Putting abortion to one side, this paper identifies why the personhood framework that is contemplated by the proposed changes does not eliminate the potential for restrictions on contraception and in vitro fertilization (IVF) that put the lives of these newly recognized persons at risk; nor should it if proponents intend to remain consistent with their position. The paper goes on to suggest what those restrictions might look like based on recent efforts being proposed at the state level and frameworks that have already been adopted in other countries.

\section{INTRODUCTION}

The United States Constitution does not define the word "person." ${ }^{1}$ More specifically, it does not clearly delineate who or what is included in the concept of "person" for purposes of bestowing the rights and protections that are found in the document. ${ }^{2}$ Nor does the Constitution tell us when life begins. ${ }^{3}$ Some may argue that defining "personhood" or "life" is best left to philosophers and theologians, but regardless of the philosophical or religious nature of these questions, the answers have profound implications for the law. ${ }^{4}$

To date, the Supreme Court of the United States has been unwilling to fully extend the concept of personhood to the preborn ${ }^{5}$ for purposes of interpreting the

\footnotetext{
${ }^{1}$ Roe v. Wade, 410 U.S. 113, 157 (1973); Jessica Berg, Of Elephants and Embryos: A Proposed Framework for Legal Personhood, 59 Hastings L.J. 369, 371 (2007).

${ }^{2}$ See Karen G. Crockett \& Miriam Hyman, Live Birth: A Condition Precedent to Recognition of Rights, 4 HOFSTRA L. REV. 805, 805 (1975) ("The question of when legal rights inhere in the unborn has never been clearly resolved.").

${ }^{3}$ See Jason M. Horst, The Meaning of "Life": The Morning-After Pill, the Question of When Life Begins, and Judicial Review, 16 Tex. J. Women \& L. 205, 206 (2006) ("The Court has been able to avoid dealing directly with [the] question of [when life begins].").

${ }^{4}$ It is not the purpose of this particular article to distinguish between concepts of "life" and "personhood." Others have taken up the important task of exploring the nature of personhood, and "thick" (conscious experience/moral agency/rationality, etc.) v. "thin" (biological) conceptions of life. See, e.g., Helga Kuhse \& Peter Singer, Individuals, Humans and Persons: The Issue of Moral Status, in EMBRYO EXPERIMENT'N 65 (Peter Singer et al. eds.,1990); Berg, supra note 1, at 375-76 (citing H. Tristram Engelhardt, JR., The Foundations of Bioethics 104 (1986)); Caitlin E. Borgmann, The Meaning of "Life": Belief and Reason in the Abortion Debate, 18 COLUM. J. GENDER \& L. 551 (2008) [hereinafter Borgmann, Meaning of Life]; Khiara M. Bridges, A Reflection on Personhood and "Life," 81 Miss. L.J. SupRA 91 (2011); Khiara M. Bridges, "Life" in the Balance: Judicial Review of Abortion Regulations, 46 U.C. DAVIS L. REV. 1285 (2013). While there is certainly more to be said on these topics, the point of this project is to explore the implications of adopting a certain "thin," biological conception of life and personhood as it relates to the potential for legal restrictions on reproductive choice.

${ }^{5}$ Interestingly, in the Supreme Court's most recent abortion decision, it went as far as to say that "by common understanding and scientific terminology, a fetus is a living organism while within the
} 
Federal Constitution. After all, even viable fetuses are not entitled to the full complement of constitutional rights and protections. Justice Scalia maintains that the Constitution would permit individual states to allow "abortions on demand," if they wish, ${ }^{6}$ and if viable fetuses are protected by the Fourteenth Amendment, then equal protection might require all post-viability abortions to be outlawed, without the exceptions some states permit for rape and incest. ${ }^{7}$

Perhaps due to the Supreme Court's reluctance in this area, federal legislation has been proposed to specifically designate when human life begins (or when persons come into existence) for purposes of federal law, ${ }^{8}$ and several states (either through legislation or constitutional amendment) have undertaken measures to adopt such a personhood framework at the state level. ${ }^{9}$ Whether in proposed legislation or state constitutional amendments, advocates within this Personhood Movement choose terms like "fertilization," or phrases such as "human being at any stage of development," to identify the person-defining moment in the reproductive process. These designations have biological and legal significance. ${ }^{10}$

Personhood proponents are outspoken in their desire to outlaw abortion, but they are less transparent about their intent with respect to contraception and infertility treatments. Since Roe v. Wade ${ }^{11}$ however, the United States Supreme Court has consistently upheld a woman's constitutional right to choose to have an abortion. ${ }^{12}$ Even if a personhood framework is adopted via statute or state constitutional amendment in an effort to outlaw abortion, it is entirely possible that the Court would strike down such provisions at least insofar as they are inconsistent with a woman's constitutionally-protected privacy right. That said, any federal constitutional protection available in the context of access to contraception or infertility treatments is more tenuous.

Courts and commentators frequently suggest that the U.S. Constitution protects a fundamental right to procreate, but the nature and scope of that right, to the extent it exists, is unclear. ${ }^{13}$ While Supreme Court precedent indicates that a state may not

womb, whether or not it is viable outside the womb." Gonzales v. Carhart, 550 U.S. 124, 147 (2007) While the Court was willing to say that the fetus is at least a living organism, it was apparently not comfortable defining the fetus as a human life or legal person entitled to the rights and protections associated therewith. See also Lisa McLennan Brown, Feminist Theory and the Erosion of Women's Reproductive Rights: The Implications of Fetal Personhood Laws and In Vitro Fertilization, 13 AM. U. J. GENDER SOC. POL'Y \& L. 87, 91 (2005) (noting that "Roe's failure to define clearly what rights to personhood a fetus may hold has allowed states to undermine the Supreme Court's holdings").

${ }^{6}$ Planned Parenthood of Se. Pa. v. Casey, 505 U.S. 833, 979 (1992) (Scalia, J., dissenting).

${ }^{7}$ Borgmann, Meaning of Life, supra note 4, at 581; Jack M. Balkin, How New Genetic Technologies Will Transform Roe v. Wade, 56 EMORY L.J. 843, 846 (2007). For arguments that abortion would be permissible even if a fetus is considered a "person," see, e.g., Judith Jarvis Thomson, A Defense of Abortion, 1 PHIL. \& PuB. AfF. 47 (1971); Eileen L. McDonagh, My Body, My Consent: Securing the Constitutional Right to Abortion Funding, 62 ALB. L. REV. 1057 (1999); Donald H. Regan, Rewriting Roe v. Wade, 77 Mich. L. Rev. 1569 (1979); Robin West, Liberalism and Abortion, 87 GEO. L.J. 2117 (1999). In addition, not all persons are entitled to the same legal rights. Children have fewer rights than adults, and indeed, the law already recognizes different definitions of persons for different contexts, as when fetuses are considered persons under certain criminal or tort statutes. Berg, supra note 1, at 373.

${ }^{8}$ See Sanctity of Human Life Act, H.R. 23, 113th Cong. (2013).

${ }^{9}$ See infra Part II.

${ }^{10}$ See infra Parts III \& IV.

${ }^{11} 410$ U.S. 113 (1973).

${ }^{12}$ See, e.g., Stenberg v. Carhart, 530 U.S. 914 (2000); Planned Parenthood of Se. Pa. v. Casey, 505 U.S. 833 (1992); Planned Parenthood v. Danforth, 428 U.S. 52 (1976).

${ }^{13}$ See generally Carter J. Dillard, Rethinking the Procreative Right, 10 YALE HuM. RTS. \& DeV. L.J. 1 (2007); John A. Robertson, Assisting Reproduction, Choosing Genes, and the Scope of 
outlaw or restrict access to all types of contraception, ${ }^{14}$ it is far less clear whether access to certain types of birth control could be restricted. ${ }^{15}$ This would be particularly true if a personhood framework passes, given that birth control's mechanism of operation is effective after fertilization has taken place. The interest in protecting the rights of these newly recognized persons could lead to restrictions on any form of contraception that is or could be effective after fertilization has occurred. Further, the Supreme Court has yet to suggest that any fundamental right to procreate includes a right to have access to infertility treatments. ${ }^{16}$ Defining fertilized ova to be persons entitled to legal protection would seem to establish a strong interest in restricting treatments that put these persons at risk of injury or death.

This lack of clarity regarding how a personhood framework might impact reproductive choice outside the abortion context has contributed to the failure of personhood measures in multiple states, and could be the reason why the federal Sanctity of Human Life Act, which was co-sponsored by Congressman and former vice-presidential candidate Paul Ryan, did not make it out of congressional committee when first proposed in 2011. ${ }^{17}$ While it may not have been surprising that personhood initiatives would be soundly defeated in a state such as Colorado, ${ }^{18}$ the late 2011 failure of a proposed personhood amendment to the Mississippi Constitution sparked drastic changes to the language utilized within the Personhood Movement. ${ }^{19}$ The revised language targets questions raised by previous iterations, but it does not dispel the most pressing concerns regarding reproductive choice. And while no state has adopted a personhood framework yet, at least nine states can

Reproductive Freedom, 76 GEO. WASH. L. REV. 1490 (2008) (examining the source of this right and its limits).

${ }^{14}$ See, e.g., Carey v. Population Servs. Int'l, 431 U.S. 679 (1977); Eisenstadt v. Baird, 405 U.S. 438 (1972); Griswold v. Connecticut, 381 U.S. 479 (1965).

${ }^{15}$ See I. Glenn Cohen, The Constitution and the Rights Not to Procreate, 60 StAn. L. REv. 1135, 1167-72 (2008).

${ }^{16}$ Note, Assessing the Viability of a Substantive Due Process Right to In Vitro Fertilization, 118 Harv. L. Rev. 2792, 2793 (2005) (citing John A. Robertson, Procreative Liberty in the Era of Genomics, 29 AM. J.L. \& MED. 439, 453 (2003) ("The Supreme Court has never directly confronted the issue of whether access to [in vitro fertilization] should be considered a constitutionally protected fundamental right.")).

17 Nadia Kounang, Could 'Personhood' Bills Outlaw IVF?, CNN (Aug. 30, 2012), http://www.cnn.com/2012/08/30/health/ivf-outlawed/index.html?hpt=he t4. While Mitt Romney and Paul Ryan were not elected on November 6, 2012, Paul Ryan was reelected to his congressional seat, and commentators suggest that his political career will continue to advance. See, e.g., Samuel P. Jacobs, Despite Loss, Paul Ryan Has Bright Future, Reuters (Nov. 6, 2012), $\mathrm{http}: / /$ news.msn.com/politics/despite-loss-paul-ryan-has-bright-future.

${ }^{18}$ One opponent of the initiatives in Colorado recalled the "resounding defeat of [the 2008] measure," and suggested that "it was a non-starter [in Colorado]." Electa Draper, "Personhood" Push Rejected, DENVER POST, Nov. 5, 2008, http://www.denverpost.com/nationalpolitics/ci_10900171.

${ }^{19}$ The substantive text of the amendments proposed in Colorado in 2008 and 2010 , and proposed in Mississippi in 2011, contained twenty words or less. See infra Part II. The revised language proposed in Colorado for the 2012 election cycle was over 200 words long. Colo. Initiative 46 (2011) (proposed COLO. CONST. art. II, $\quad$ 32), available at http://www.sos.state.co.us/pubs/elections/Initiatives/titleBoard/filings/2011-2012/46Final.pdf [hereinafter Appendix I] (the proposal did not receive the requisite number of signatures to get on the 2012 ballot). For the full text of the 2012 Colorado proposal, see infra Appendix I. Colorado Personhood Amendment Falls Short of Required Signatures to Make Ballot, HufFInGTON Post (Aug. 30, 2012), http://www.huffingtonpost.com/2012/08/29/colorado-personhood-amend_n_1840602.html. Similar language was put forward recently in Arkansas, but the Attorney General of Arkansas rejected the proposal. See Ark. Att'y Gen. Op. No. 2012-02 (2012), available at http://ag.arkansas.gov/opinions/docs/2012-002.pdf. 
expect to see personhood measures in coming years. ${ }^{20}$ As of March 2013, the North Dakota Senate and House approved an initiative (which will now appear on the November 2014 ballot) to amend the state constitution to protect "the inalienable right to life of every human being at any stage of development."21

How we define "person," or at what point rights attach to human life, will directly impact all things surrounding the reproductive process, regardless of the intent with which that process begins. It is true that such answers will affect the choices available to women once pregnant, but they will also inevitably impact such things as the availability of certain birth control options, and the permissiveness of various forms of assisted reproductive technologies (ART).

The purpose of this article is to show why the revisions found in new personhood proposals at the state level ${ }^{22}$ do not adequately address the concerns raised regarding potential implications for reproductive choice. If a personhood framework is adopted, it is likely that restrictions on certain birth control methods and ART would soon follow. In a future article I will argue that, given the uncertainty regarding the nature and scope of any procreational liberty protected by the Constitution, it is very possible that such restrictions would be upheld. ${ }^{23}$ In short, regardless of the implications for abortion, certain forms of contraception and infertility treatments are particularly susceptible to successful restriction in the event that a personhood framework is adopted through legislation or state constitutional amendment. $^{24}$

To that end, Part II of the present article will provide a brief background of the Personhood Movement, including the unexpected failure of the proposed amendment to the Mississippi Constitution. Part III will explore the nature of the debates in Mississippi to provide context for debates likely to be held elsewhere, and will also introduce revisions made within the Personhood Movement to the language of future proposals in response to the failure in Mississippi. Part IV will then discuss how an understanding of the relevant biology and physiology of the reproductive process - including contraception and IVF-demonstrates why the new language being proposed within the Personhood Movement should not prove satisfying for those concerned about the potential for significant restrictions on reproductive choice. This is not to say that all such reproductive choices would be banned outright, but Part IV will also offer examples of what those restrictions might look

${ }^{20}$ See Personhood Bills and Ballot Initiatives, RESOLVE: NAT'L INFERTILITY ASS'N, http://www.resolve.org/get-involved/personhood-bills-and-ballot-initiatives.html (last visited Oct. 16, 2013). Further, as the political atmosphere changes, Congress may also revisit the Sanctity of Human Life Act.

${ }^{21}$ Laura Bassett, North Dakota Personhood Measure Passes State Senate, Huffington Post (Feb. 8, 2013), http://www.huffingtonpost.com/2013/02/07/north-dakota-personhood_n_2640380.html [hereinafter Bassett, Senate]; Laura Bassett, North Dakota Personhood Measure Passes State House, HufFington POST (Mar. 22, 2013), http://www.huffingtonpost.com/2013/03/22/north-dakotapersonhood_n_2934503.html [hereinafter Bassett, House].

${ }^{22}$ The language used in the Sanctity of Human Life Act is similar to early iterations of state personhood proposals, and it thus raises the same issues regarding reproductive choice as those earlier measures. See infra Parts III \& IV. See generally Sanctity of Human Life Act, H.R. 23, 113th Cong. (2013).

${ }^{23}$ Jonathan F. Will, Beyond Abortion: Pre-Embryonic Personhood and the Constitutionality of Restrictions on Reproductive Choice (2013) (unpublished manuscript) (on file with author).

${ }^{24}$ See Erik Eckholm, Push for 'Personhood' Amendment Represents New Tack in Abortion Fight, N.Y. TIMES, Oct. 25, 2011, http://www.nytimes.com/2011/10/26/us/politics/personhood-amendmentswould-ban-nearly-all-abortions.html?pagewanted=all (suggesting the proposed Personhood Amendment would ban not only most abortions, but also "some birth control methods, including IUDs and 'morning-after pills"'). 
like under a personhood framework, assuming proponents intend to remain consistent with the position.

\section{PERSONHOOD MOVEMENT}

\section{A. BACKGROUND}

Since the Supreme Court acknowledged a woman's fundamental right to choose to terminate her pregnancy forty years ago, ${ }^{25}$ abortion opponents have been struggling to limit women's ability to exercise that right. Over these decades, the Court has heard dozens of cases addressing the constitutionality of various restrictions on abortion. ${ }^{26}$ While Casey undoubtedly made it easier for states to impose such restrictions, ${ }^{27}$ nothing short of an absolute prohibition on abortion will appease the staunchest opponents. Acknowledging the "personhood" of the preborn is thought to be an avenue toward establishing a framework that would achieve this goal without direct reference to abortion. ${ }^{28}$

Proponents of the now nationwide Personhood Movement use as their starting point Justice Blackmun's language ${ }^{29}$ in Roe that "[i]f this suggestion of [fetal] personhood is established, the appellant's case [arguing in favor of women's choice], of course, collapses, for the fetus' right to life would then be guaranteed specifically by the [Fourteenth] Amendment." ${ }^{30}$ The logic being, that if the legal personhood of fetuses is established, then this would prompt federal constitutional protection of the fetuses' lives ${ }^{31}$ at the expense of women's choice.

\footnotetext{
${ }^{25}$ Roe v. Wade, 410 U.S. 113, 169-70 (1973).

${ }^{26}$ See, e.g., Planned Parenthood of Se. Pa. v. Casey, 505 U.S. 833 (1992); H.L. v. Matheson, 450 U.S. 398 (1981); Planned Parenthood v. Danforth, 428 U.S. 52 (1976).

${ }^{27}$ Casey, 505 U.S. at $872-75$ (finding that in the past the Court had been too quick to strike down state restrictions using strict scrutiny analysis and substituting that analysis with the undue burden standard moving forward).

${ }^{28}$ Excluded from this discussion are state statutes proposed either by citizens or the legislature with language explicitly attempting to restrict abortion. For instance, unsuccessful attempts were made in Oklahoma and Wyoming in the early 1990s to prohibit abortion except in the narrowest of circumstances. See Molly E. Carter, Note, Regulating Abortion Through Direct Democracy: The Liberty of All Versus the Moral Code of a Majority, 91 B.U. L. REv. 305, 307 (2011) (citing In re Initiative Petition No. 349, 838 P.2d 1, 3 (Okla. 1992) and Wyo. Nat'l Abortion Rights Action League v. Karpan, 881 P.2d 281, 289 (Wyo. 1994)). A similar effort failed in South Dakota in 2006. See Borgmann, Meaning of Life, supra note 4, at 560. Also excluded from this discussion are statutes contingently enacted by certain states to ban abortion that would take effect if the Court overturns Roe. Id. at 560-61 n.50.

${ }^{29}$ See What is Personhood?, PERSONHOOD USA, http://www.personhoodusa.com/about-us/whatis-personhood (last visited Nov. 1, 2013) (indicating that "personhood holds the key to filling the 'Blackmun Hole'”).

${ }^{30}$ Roe, 410 U.S. at 156-57. But cf. Thomson, supra note 7; Regan, supra note 7; West, supra note 7; and McDonagh, supra note 7 (arguing that abortion would be permissible even if a fetus is considered a "person"). Even a strong personhood proponent acknowledges in his Doctor of Juridical Science dissertation that Justice Blackmun was likely too quick in his assessment. See Charles L. Lugosi, Conforming to the Rule of Law: When Person and Human Being Finally Mean the Same Thing in Fourteenth Amendment Jurisprudence, 22 Issues L. \& MED. 119, 289 (2006) (stating that Blackmun "may have been premature in suggesting the case for abortion collapses once the unborn human being attains constitutional personhood, if credence is given to emergent new views that justify abortion of constitutional persons").

${ }^{31}$ See About Us, PERSONHOOD USA, http://www.personhoodusa.com/about-us (last visited Oct. 31, 2013) [hereinafter About Personhood] (stating that Personhood USA intends "to build the support of at least two thirds of the states in an effort to reaffirm personhood within the U.S. Constitution").
} 
Regardless of whether, in fact, state definitions of personhood (or federal statutory definitions) have any impact on the interpretation of the Federal Constitution, ${ }^{32}$ personhood proponents are clear in their intent to challenge the legal underpinnings of the Supreme Court's abortion jurisprudence. ${ }^{33}$ While statutes or state constitutional amendments that define personhood may not be effective themselves in outlawing abortion, the hope is that a challenge to any such statute or amendment would make its way to the Supreme Court, giving the Court an opportunity to overturn its prior decisions regarding abortion. ${ }^{34}$

The increased wave of attempts by states in the last five years ${ }^{35}$ to establish a personhood framework through statute or constitutional amendment can fairly be attributed to the work of Kristi Burton. ${ }^{36}$ In 2008, Ms. Burton worked with Colorado for Equal Rights to qualify a voter initiative that proposed an amendment (Amendment 48) to the Colorado Constitution. ${ }^{37}$ The text of this initiative, and that of more recent personhood measures, ${ }^{38}$ does not mention abortion, nor does it include the subordinating language found in Missouri's preamble. ${ }^{39}$

${ }^{32}$ Professor Borgmann illustrates the point this way: "a state could define a cow as a 'person' under state law. In such a case, the [United States Supreme] Court would still have to answer whether this recognition violated the constitutional rights of anyone recognized as a person under the [F] ederal Constitution." Borgmann, Meaning of Life, supra note 4, at 576 n.118. In other words, personhood initiatives themselves would not necessarily outlaw abortion. Unless Roe is overturned, the Court would have to consider the extent to which recognition of preborn "personhood" restricts Roe's acknowledgment of women's constitutional right to choose to have an abortion. See also Carter, supra note 28, at 307 (discussing the appropriateness of using the democratic process to resolve the abortion debate, and citing In re Initiative Petition No. 349, 838 P.2d 1, 11 (Okla. 1992) for the proposition that the initiative process "was never intended to be a vehicle for amending the United States Constitution-nor can it serve that function in our system of government").

${ }^{33}$ What is Personhood, supra note 29 (stating that "to be a person is to be protected by a series of God-given rights and constitutional guarantees such as life, liberty, and the pursuit of happiness. This terrifies the pro-abortion foes! They know that if we clearly define the preborn baby as a person, they will have the same right to life as all Americans do.”).

${ }^{34}$ The Supreme Court of Oklahoma recently vetoed personhood language similar to that which was proposed in Colorado in 2012. See Randy Krehbiel, Group Requests Personhood Appeal from U.S. Supreme Court, TUlSA WORLD, July 31, 2012, http://www.tulsaworld.com/site/printerfriendlystory.aspx?articleid=20120731_16_a9_clrdae519381 (expressing Personhood USA's hope that the United States Supreme Court will use the dispute surrounding Oklahoma's proposed personhood amendment as an opportunity to overturn Casey [and thereby Roe]). The United States Supreme Court has since denied certiorari in the case. In re Initiative No. 395, State Question No. 761, 286 P.3d 637 (Okla. 2012), cert. denied, Personhood Okla. v. Barber, 133 S. Ct. 528 (2012).

${ }^{35}$ Over twenty years ago, a statute regulating abortions was introduced in Missouri that included a preamble stating that "“[t]he life of each human being begins at conception,' and that 'unborn children have protectable interests in life, health, and well-being." Webster v. Reprod. Health Servs., 492 U.S. 490, 501 (1988) (quoting Mo. REV. STAT. § 1.205.1(1)-(2) (1986)). But unlike modern personhood proposals, the Missouri statute expressly subordinates itself to Supreme Court precedent, including Roe, and because the statute had not been used to restrict women's rights in violation of Roe, when the statute was challenged, the Court determined that it did not have to pass upon the constitutionality of the preamble. Webster, 492 U.S. at 506-07.

36 Adam Cayton-Holland, Meet Kristi Burton, The 21-Year-Old Pro-Lifer Behind The Personhood Amendment, WeSTwORD News, Sept. 25, 2008, http://www.westword.com/2008-0925/news/meet-kristi-burton-the-22-year-old-pro-lifer-behind-the-personhood-amendment/.

${ }^{37}$ Leslie Jorgensen, Personhood Amendment Revised and Revived, Colorado StATESMAN, July 3, 2009, http://www.coloradostatesman.com/content/991130-personhood-amendment-revised-andrevived.

${ }^{38}$ See supra note 19; see infra Appendix I. This discussion is focused on efforts by states to avoid specifically mentioning abortion by defining the term "person" to include the preborn through statute or constitutional amendment.

${ }^{39}$ For the relevant text of Missouri's preamble, see supra note 35. 
Specifically, proposed Amendment 48 sought to add a new section to the Colorado Constitution that would have simply read "Section 31. Person defined. As used in sections 3, 6, and 25 of article II of the state constitution, the terms 'person' or 'persons' shall include any human being from the moment of fertilization." 40 Although seventy-three percent of the Colorado electorate voted against this proposal, the day after the vote, Keith Mason founded Personhood USA to continue the effort. ${ }^{41}$

Personhood USA is a national organization with many regional affiliates ${ }^{42}$ that identifies itself as a non-profit Christian ministry that "serves the pro-life community by assisting local groups to initiate citizen, legislative, and political action focusing on the ultimate goal of the pro-life movement: personhood rights for all innocent humans." ${ }^{\text {43 }}$ Among other things, the organization is committed to "moving churches and the culture to make the dehumanization and murdering of preborn children unthinkable." ${ }^{44}$ Some have suggested that the Personhood Movement is simply about returning to first principles, ${ }^{45}$ and Personhood USA itself is very specific: the movement is about "working to respect the God-given right to life recognizing all human beings as persons who are 'created in the image of God' from the beginning of their biological development, without exceptions." ${ }^{46}$ This language expressly adopts a thin, biological definition of life and personhood, ${ }^{47}$ and there is nothing on its face limiting its applicability to abortion.

Although the position is subject to challenge as being inappropriately speciesest, proponents maintain that the only criterion relevant to assigning the protections associated with legal personhood is membership in the Homo sapiens species. ${ }^{48}$ After all, under the revised language every human being is a "person," and human beings include "every member of the species $[\mathrm{H}]$ omo sapiens at any stage of development." 49 The Sanctity of Human Life Act similarly states that "human being" includes "every member of the species $[\mathrm{H}]$ omo sapiens at all stages of life." 50

${ }^{40}$ See Colo. Initiative 36 (2008) (proposed Colo. Const. art II, $\S 23$ ), available at http://www.sos.state.co.us/pubs/elections/Initiatives/titleBoard/filings/2007-2008/Final36-0708.pdf.

41 Abigail Pesta, Behind 'Personhood' Leader Keith Mason's Anti-Abortion Crusade, NEWSWEEK (June 25, 2012), http://mag.newsweek.com/2012/06/24/personhood-usa-s-keith-masoneyes-election-day-2012.html.

${ }^{42}$ See, e.g., Colo. Personhood Coalition, http://personhoodco.com (last visited Oct. 20 , 2013); Personhood Fla., http://personhoodfl.com (last visited Oct. 20, 2013); Personhood Miss., http://www.personhoodmississippi.com (last visited Oct. 20, 2013); PERSONHOOD N.D., http://personhoodnorthdakota.com (last visited Oct. 20, 2013); PERSONHOOD OKLA., $\mathrm{http} / / /$ personhoodoklahoma.com/news (last visited Oct. 20, 2013); PERSONHOOD WIS., http://www.personhoodwisconsin.com (last visited Oct. 20, 2013).

${ }^{43}$ See About Personhood, supra note 31.

${ }^{44} \mathrm{Id}$.

${ }^{45}$ See, e.g., Daniel C. Becker, Personhood: A Pragmatic Guide to Prolife Victory in The 21st Century and the Return to First Principles in Politics (2011).

${ }^{46}$ About Personhood, supra note 31.

${ }^{47}$ See supra note 4 and infra note 178 .

${ }^{48}$ E.g., Jonathan Will et al., When Potential Does Not Matter: What Developments in Cellular Biology Tell Us About the Concept of Legal Personhood, 13 AM. J. Bioethics 38, 39 (2013) (citing generally to Peter Singer, Animal Liberation: A New Ethics for Our Treatment of Animals (1975)). Under this view, the belief that human life should be protected because it is innately valuable or "sacred just in itself" is detached from any requirement that the life in question has interests of its own. RONALD DWORKIN, LIFE's DOMINION 11-13 (1993).

${ }^{49}$ See infra Appendix I.

${ }^{50}$ Sanctity of Human Life Act, H.R. 23, 113th Cong. § 3(3) (Jan. 2013). 
Further, proponents are clear that for them membership in the species begins at the outset of biological development. ${ }^{51}$

This approach stands in contrast to other ways in which we might define legal or moral personhood. For instance, one might agree with the human species concept, yet maintain that membership does not occur until a later time in development, such as the appearance of the primitive streak around fourteen days after fertilization, ${ }^{52}$ or when other evidence of "life" is present like a detectable heartbeat (five to six weeks) $)^{53}$ or electrical activity in the early brain (eight weeks).$^{54}$ One could also assign legal or moral personhood to a pre-embryo ${ }^{55}$ not because of its current state, but because it has the potential to develop into a born human being. ${ }^{56}$ Yet another approach rejects the significance of membership in the Homo sapiens species, and instead would attach legal or moral personhood at the point when the developing organism attains certain capacities, such as the capacity to experience pain ${ }^{57}$ or for rational thought or self-consciousness. ${ }^{58}$ Interestingly, one could try to identify fetal viability as the person-defining criterion using any of these approaches. For instance, membership in the species could be deemed to begin at viability; or a fetus might be considered to have sufficient potential of becoming a born human at the point of viability such that it is then worthy of legal protection; or, as the Supreme Court noted in Roe, one could say that at viability the fetus has the capacity for

${ }^{51}$ See infra notes 173-189 and accompanying text (discussing the biology of early human development). The argument generally raised in support of this position is that once the egg and sperm have united, a unique genetic human being exists. CYNTHIA B. CoHEn, RENEwING THE STUFF OF LifE: Stem Cells, Ethics, ANd Public Policy 61-67 (2007) (identifying and critiquing this position).

${ }^{52}$ COHEN, supra note 51 , at 68.

${ }^{53}$ David F. Forte, Life, Heartbeat, Birth: A Medical Basis for Reform, 74 Оніо ST. L.J. 121, 14043 (2013). The heart may begin to beat as early as twenty-two days after fertilization. Kirsten Rabe Smolensky, Defining Life from the Perspective of Death: An Introduction to the Forced Symmetry Approach, 2006 U. Chi. Legal F. 41, 81 n.200 (citing William J. LaRSEn, Human Embryology $166(2001))$.

${ }^{54}$ Smolensky, supra note 53, at 69-70.

55 "Pre-embryo" will be the term used throughout this paper to refer to the fertilized ovum from the time the sperm penetrates the egg until roughly two weeks later when the primitive streak develops and/or implantation is complete. See Davis v. Davis, 842 S.W.2d 588, 592-94 (Tenn. 1992) (detailing scientific justification for distinguishing between the terms "embryo" and "pre-embryo"). Not all commentators support making this terminological distinction. See, e.g., Louis M. Guenin, On Classifying the Developing Organism, 36 CONN. L. REV. 1115 (2004) (arguing that these distinctions do not add value to moral discussions regarding such things as embryonic stem cell research). $C f$. Ann A. Kiessling, What is an Embryo?, 36 CONN. L. REV. 1051 (2004) (arguing that use of the technical terms informs our understanding of the morality of these activities).

${ }^{56}$ See, e.g., CoHEN, supra note 51, at 73-78; Marco Stier \& Bettina Schoene-Seifert, The Argument from Potentiality in the Embryo Protection Debate: Finally 'Depotentialized'?, 13 AM. J. BIOETHICs 19 (2013) (identifying and critiquing this position); Will et al., supra note 48 (discussing arguments from potentiality and how any determination of when there is sufficient "potential" to warrant legal protection is subject to a charge of arbitrariness).

${ }^{57}$ See I. Glenn Cohen \& Sadath Sayeed, Fetal Pain, Abortion, Viability, and the Constitution, 39 J.L. MED. \& Ethics 235, 240 (2011) (identifying and challenging the argument "that the capacity to feel pain is itself a criterion of constitutional personhood" that could be raised in defense of Nebraska's statute outlawing abortion at twenty-weeks' gestation).

${ }^{58}$ COHEN, supra note 51, at 81-83 (identifying and critiquing this position). Peter Singer is well known for his support of this position, which is willing to assign personhood to certain high functioning, non-human species while withholding the designation from certain low-functioning humans. Id. (citing generally to Peter Singer, Practical Ethics (1993)). See also John A. Robertson, In the Beginning: The Legal Status of Early Embryos, 76 VA. L. REV. 437, 444-46 (1990) (noting the difference between the human species approach and the capacity approach). Proponents of the Personhood Movement obviously reject any notion that sentience or conscious experience is a prerequisite to attaching moral worth and full legal protection to the human life in question. 
"meaningful life outside the mother's womb," protecting fetal life compelling at that point.

In an interesting article, Jessica Berg outlines a different kind of personhood framework ${ }^{60}$ where she suggests that a claim to the protections of legal personhood in the context of the non-sentient (those without interests or consciousness) must be based not on the entity's own interests (since it has none), but on the protection of interests of others. ${ }^{61}$ She further argues that legal protection of the non-sentient may be more limited than that afforded to persons with interests. ${ }^{62}$

By way of example, Professor Berg points out that at birth, the law currently protects the life of even non-sentient human beings, such as an anencephalic infant who lacks the cortical structures necessary for consciousness, not because the anencephalic infant herself has a claim to protection of her own interests, but "because there is a societal interest in encouraging specific caring behaviors towards all infants (and discouraging other behaviors such as infanticide)." ${ }^{63}$ This is important since, at least in part, the suggestion could be made that because anencephalic infants appear very much like newborn babies with normal cortical function, a societal interest exists in protecting them as legal persons notwithstanding their lack of their own interests. ${ }^{64}$ Another example can be seen in Gonzales v. Carhart, where the Court references Congress' statement that permitting partial-birth abortions in the second trimester (at which point the fetus has recognizably human features) would "further coarsen society to the humanity of not only newborns, but all vulnerable and innocent human life, making it increasingly difficult to protect such life." ${ }^{\prime 65}$ But the same would arguably not be true for the entity existing very early in biological development (say a single-celled zygote, which does not appear to share many characteristics with a newborn person), and this may suggest that the interests of others would not be sufficient at this earlier stage to protect this non-sentient entity as a legal person. ${ }^{66}$

But those in support of the Personhood Movement would counter that society has a sufficient interest in acknowledging the value of and offering protection to all members of the Homo sapiens species without regard to sentience. In fact, the devaluing of what is considered to be human life (by not protecting it) is considered by personhood proponents to be a great detriment to societal interests. ${ }^{67}$ How early in the developmental process the Court would acknowledge such a societal or stateasserted interest is unclear. But in this regard, it is interesting to note that the Personhood Movement appears (even if inadvertently) to be taking Justice Rehnquist up on his suggestion in Cruzan (in the end-of-life context) that States "may properly decline to make judgments about the 'quality' of life that a particular person may enjoy and may simply assert an unqualified interest in the preservation of human

\footnotetext{
${ }^{59}$ Roe v. Wade, 410 U.S. 113, 163 (1973).

${ }^{60}$ Berg, supra note 1, at 375-79.

${ }^{61} \mathrm{Id}$. at 376 ; cf. DWORKIN, supra note 48 , at 11-13 (describing the "detached objection to abortion," which is a claim against abortion based on the belief that human life has intrinsic value regardless of whether the human has its own interests).

${ }^{62}$ Berg, supra note 1 , at 376 . It is on this point that Personhood proponents would surely disagree.

${ }^{63} \mathrm{Id}$. at 378 .

${ }^{64} \mathrm{Id}$. at 387 .

${ }^{65}$ Gonzales v. Carhart, 550 U.S. 124, 157 (2007).

${ }^{66}$ Berg, supra note 1 , at 391 . John Robertson has argued that pre-embryos are owed special (though not full) protection based on their potential to become human, and because they are symbols of human life. Robertson, supra note 58, at 446-48.

${ }^{67}$ See supra notes $46-49$ and accompanying text.
} 
life. ${ }^{\prime 68}$ In a sense then, personhood efforts seem to support the claim made by Justice Stevens in his dissenting opinion in Cruzan, that when a state asserts such an unqualified interest in protecting life (even in the end-of-life context), it is really "an effort to define life, rather than to protect it."

The Personhood Movement, at its core, is about adopting a "thin," unqualified, and biological definition of personhood that would attach full moral status and legal protection to the life of the preborn and place them on equal footing with the born, ${ }^{70}$ and in 2010 Personhood USA successfully placed another citizen-driven constitutional amendment on the ballot in Colorado. ${ }^{71}$ The language the second time around was slightly different. ${ }^{72}$ The 2010 version was intended to apply to the same constitutional provisions, but this time the proposed amendment stated that the terms "person" or "persons" shall apply "to every human being from the beginning of the biological development of that human being." ${ }^{73}$ Here the term fertilization was removed, and the stated reason for this change was to broaden the scope to make sure that the provision included any persons created through asexual reproduction, like cloning. ${ }^{74}$ As occurred in $2008,{ }^{75}$ opponents of the 2010 measure raised concerns that the proposal would have impacts on contraception, fertility treatments, and the medical treatment of pregnant women. ${ }^{76}$ These concerns were publicly labeled as scare tactics by Personhood USA, ${ }^{77}$ but although the language of the initiative was different, the result was the same, with the Colorado electorate voting against the 2010 proposed amendment by a margin of three to one. ${ }^{78}$ After resounding defeats in Colorado, ${ }^{79}$ Personhood USA directed its efforts at arguably

\footnotetext{
${ }^{68}$ Cruzan v. Dir., Mo. Dep't of Health, 497 U.S. 261, 282 (1990).

${ }^{69} \mathrm{Id}$. at 344 (Stevens, J., dissenting).

${ }^{70}$ See infra Parts III \& IV for the implications of such a framework.

71 Colo. Initiative 25 (2010) (proposed COLO. Const. art II, $\S 23$ ), available at http://www.sos.state.co.us/pubs//elections/Initiatives/titleBoard/filings/2009-2010/25Final.pdf.

${ }^{72}$ Compare id. with Colo. Initiative 36 (2008) (proposed Colo. ConsT. art II, § 23), available at http://www.sos.state.co.us/pubs/elections/Initiatives/titleBoard/filings/2007-2008/Final36-0708.pdf.

${ }^{73}$ Colo. Initiative 25 (proposed COLO. CONST. art II, § 23)

${ }^{74}$ Jorgenson, supra note 37. See also Dianne N. Irving, Problems with Colorado 's "Personhood" Amendment: The Phrase, "From the Moment of Fertilization," LifeIssues.Net (May 31, 2008), http://www.lifeissues.net/writers/irv/irv_126colorado.html (suggesting that the term "fertilization" would not encompass naturally occurring twinning or the use of cloning).

${ }^{75}$ Draper, supra note 18.

${ }^{76}$ Electa Draper, "Personhood" Amendment Fails by 3-1 Margin, DenVer Post, Nov. 3, 2010, http://www.denverpost.com/election2010/ci_16506253.

${ }_{77}^{7}$ Jorgenson, supra note 37.

${ }^{78} \mathrm{Id}$. Interestingly, far less money was raised in campaign efforts the second time around. In 2008, supporters of Amendment 48 raised over $\$ 350,000$, while opponents raised in excess of $\$ 1.8$ million, but in 2010 those numbers were down to around $\$ 50,000$ and $\$ 578,000$, respectively. Id.; Draper, supra note 75.

${ }^{79}$ In 2010 an Alaskan citizen proposed an amendment to existing state legislation that sought to "protect the natural right to life and body of all mankind from the beginning of biological development," and stated that "the natural right to life and body of the unborn child supercedes [sic] the statutory right of the mother to consent to the injury or death of her unborn child." Alaska Natural Right to Life Initiative (2011) (proposed ALASKA CONST. art I, § 18.01), available at http://www.elections.alaska.gov/petitions/10NRTL/10NRTL_Sponsor_Language.pdf (last visited Oct. 31, 2013). Alaska's Lieutenant Governor rejected the initiative after determining that he was "convinced the controlling case law [including Roe] made [the initiative] clearly unconstitutional," because both the Alaska and Federal Constitutions protect a woman's right to privacy. Pat Forgey, State Rejects Anti-Abortion Ballot Measure, JunEAU EMPIRE (Jan. 12, 2011), http://juneauempire.com/stories/011211/loc_768878153.shtml. For a discussion of legislative efforts in Georgia, Louisiana, and North Dakota targeted more directly at reproductive technologies, see infra Part IV.
} 
the most conservative state in the Union ${ }^{80}$ in the 2011 election cycle. ${ }^{81}$

\section{B. PERSONHOOd GoES TO MississipPI}

Like Colorado's Constitution, the Mississippi Constitution can be amended by citizen initiative ${ }^{82}$ and, if it had passed, Measure 26 would have amended the Bill of Rights of the Mississippi Constitution to define the term "person" or "persons" to "include every human being from the moment of fertilization, cloning, or the functional equivalent thereof." 83

Unlike in Colorado, where pre-election polling in both $2008^{84}$ and $2010^{85}$ foretold the defeat of personhood initiatives there, some initial reports in Mississippi showed an excess of eighty percent of the electorate in favor of Measure $26 .{ }^{86}$ Indeed, candidates running for office on both the Republican and Democratic tickets-including both candidates for Governor-expressed open support for the amendment. ${ }^{87}$ As the election neared, however, support within the populace began to wane, and on November 8, 2011, Measure 26 failed with nearly fifty-eight percent of the electorate voting against it. ${ }^{88}$

Immediately after the election, analysts began the work of determining what caused such an unexpected collapse. ${ }^{89}$ One commentator identified several possible reasons for the failure. ${ }^{90}$ For one, the language was poorly drafted, ${ }^{91}$ and its inherent

${ }^{80}$ See, e.g., Jeffrey M. Jones, Mississippi Rates as the Most Conservative U.S. State, GaLluP Politics (Feb. 25, 2011), http://www.gallup.com/poll/146348/mississippi-rates-conservativestate.aspx.

${ }_{81}$ See generally Jonathan F. Will, Measure 26: Fear Mongering, Self-Execution \& Potential Implications for Birth Control, 81 Miss. L.J. SUPRA 63 (2011) [hereinafter Will, Measure 26] (describing personhood efforts in Mississippi).

${ }^{82}$ Miss. CONST. art XV, § 273.

${ }^{83}$ Miss. Initiative 26 (2011) (proposed MISS. CONST. art. III, § 33), available at http://www.sos.ms.gov/initiatives/Definition\%20of\%20Person-PW\%20Revised.pdf.

${ }^{84}$ Bente Birkeland, 'Personhood' Amendment on Colorado Ballot, NPR (Oct. 29, 2008), http://www.npr.org/templates/story/story.php?storyId=96167092.

${ }^{85}$ Steven Ertelt, Second Poll: Colorado Personhood Amendment Likely to Lose, LiveNews.Com (Oct. 25, 2010), http://www.lifenews.com/2010/10/25/state-5601/.

${ }^{86}$ Peter Roff, Mississippi Voters May Change Abortion Debate, U.S. News (Oct. 14, 2011), http://www.usnews.com/opinion/blogs/peter-roff/2011/10/14/mississippi-voters-may-change-abortiondebate.

${ }^{87} I d$.

${ }^{88}$ Miss. SeC'y of State, Official Tabulation of Vote for Statewide Initiative Measure No. 26

http://www.sos.ms.gov/links/elections/results/statewide/Statewide\%20Initiative\%20Measure $\% 2026 \%$ 20-\%20General\%20Election\%202011\%20Results.pdf (last visited Nov. 1, 2013). In March of 2013, Ann Reed submitted a new personhood proposal to the Mississippi Secretary of State that would amend the state constitution by adding a new section that would read: "The right to life begins at conception. All human beings at every stage of development are unique, created in the image of God, and shall enjoy the inalienable right to life as persons under the law." Meet the Sponsor, PERSONHOOD Miss. (Mar. 5, 2013), http://www.personhoodmississippi.com/home-featured/meet-the-sponsor-of-thelife-at-conception-citizens-intiative/.

${ }^{89}$ See Mississippi Anti-Abortion 'Personhood' Amendment Fails at Ballot Box, WaSH. Post, Nov. 9, 2011, http://www.washingtonpost.com/politics/mississippi-anti-abortion-personhoodamendment-fails-at-ballot-box/2011/11/09/gIQAzQ195M_story.html.

${ }^{90}$ Burns Strider, 6 Reasons Mississippians Said No to "Personhood" Amendment, Huffington Post (Nov. 8, 2011), http://www.huffingtonpost.com/burns-strider/personhood-amendment_b_1083079.html.

${ }_{91}$ Id. 
ambiguities $^{92}$ saw the same concerns previously seen in Colorado raised regarding potential impacts on the treatment of pregnant women, restrictions on contraception, and restrictions on IVF. ${ }^{93}$ In addition, major religious figures, like Episcopal, Methodist, and Catholic Bishops in Mississippi did not support the measure, nor did the president of the Mississippi NAACP. ${ }^{94}$ Interestingly, while outgoing Governor Haley Barbour ultimately voted in favor of the initiative, he first publicly voiced his concerns about it. ${ }^{95}$ Finally, Personhood USA faced stauncher opposition in conservative Mississippi than it may have anticipated. ${ }^{96}$ Local groups like Mississippians for Healthy Families ${ }^{97}$ and Parents Against $26^{98}$ organized efforts in opposition to the amendment, which reached thousands of citizens. ${ }^{99}$

For its part, Personhood USA performed exit polling in an attempt to discover what caused the unanticipated defeat in Mississippi. ${ }^{100}$ The poll suggested that the amendment's failure could not be attributed to a large group of previouslyunidentified abortion-rights voters in Mississippi; rather, only $8 \%$ of the ten thousand people polled indicated that they voted against the measure because they identify themselves as "pro-choice." ${ }^{101}$ A greater percentage (12\%) said that they voted against Measure 26 because then-Governor Haley Barbour expressed concerns about it. ${ }^{102}$ But the two most common reasons indicated for voting against the initiative had to do with potential implications for (a) the medical treatment of pregnant women $(28 \%)$, and (b) the availability of IVF $(31 \%) .^{103}$

When reporting the results of this polling, Personhood USA noted that proponents of Measure 26 had repeatedly said that "the amendment could not ban in vitro fertilization, contraception, or healthcare for women," but that "Planned Parenthood (under the guise of Mississippians for Healthy Families), persisted in lying to Mississippi voters, propagating scare tactics that were proven false numerous times." 104 From Personhood USA's perspective, the poll made clear that

\footnotetext{
${ }^{92}$ See I. Glenn Cohen \& Jonathan F. Will, Op-Ed, Mississippi's Ambiguous 'Personhood' Amendment, N.Y. TIMES, Oct. 31, 2011, http://www.nytimes.com/2011/10/31/opinion/mississippis ambiguous-personhood-amendment.html.

${ }^{93}$ See, e.g., Elizabeth Crisp, Mississippians to Vote on 'Personhood' Initiative, USA TODAY, Nov. 6, 2011, http:/www.usatoday.com/news/nation/story/2011-11-06/mississippi-voters-to-vote-onpersonhood-initiative/51098740/1; Will, Measure 26, supra note 81, at 64; Jonathan F. Will, Op-Ed, Life and Law-The Commitment to Pre-Embryonic Personhood, Miss. Bus. J. (Sep. 23, 2011), http://msbusiness.com/2011/09/op-ed-life-and-law- $\%$ E2\%80\%94\%C2\%A0the-commitment-to-preembryonic-personhood/ [hereinafter Will, Life and Law]. In addition to writing on the topic, I organized a panel at Mississippi College School of Law to discuss the amendment and its potential implications. See infra note 118 and accompanying text.

${ }_{95}^{94}$ Strider, supra note 90.

${ }^{95} \mathrm{Id}$.

${ }^{96}$ Id.

${ }^{97}$ Personhood USA was adamant that Mississippians for Healthy Families was a front for Planned Parenthood and the ACLU. See Live Action and Personhood USA Release New Sting Operation in Mississippi Before Personhood Vote, PRWEB (Oct. 31, 2011), http://www.prweb.com/releases/2011/10/prweb8924956.htm. 2013).

${ }^{98}$ See generally PARENTS AGAINST MS 26, http://parentsagainstms26.com (last visited Nov. 1,

${ }^{99}$ Strider, supra note 90.

100 Keith Ashley, New Poll Reveals Real Reason Behind Mississippi Personhood Loss, PERSONHOOD USA (Nov. 22, 2011), http://cm.personhoodusa.com/press-release/new-poll-revealsreal-reason-behind-mississippi-personhood-loss.

${ }_{101}^{101}$ Id.
${ }_{103}$ Id Id.
${ }^{104}$ Id.
} 
"Planned Parenthood's willful deceit, which also raised doubts in the mind of Governor Haley Barbour, caused the defeat of [Measure] 26."105

In response to Planned Parenthood's perceived lies, Personhood USA drastically revised the language to be used in future personhood efforts. ${ }^{106}$ In Mason's own words, the "new personhood language prevents those falsehoods by making it absolutely clear what the amendment can and cannot do-while still protecting every child from his or her earliest stages." ${ }^{107}$ In order to fully appreciate the revisions made, ${ }^{108}$ and how "absolutely clear" ${ }^{109}$ they really are, it is first necessary to understand the nature of the debates in Mississippi to provide context to the broader debates concerning personhood. As it turns out, not all of the proponents of Measure 26 were consistent in what they believed the amendment could and could not (or should and should not) do.

\section{DEBATING PERSONHOOD}

There were two primary and related questions that drove most of the discussions surrounding Measure 26 leading up to the vote: (1) what would (or could) happen immediately after the amendment became effective were it to pass; and (2) what impact, if any, would the amendment have on (a) the treatment of pregnant women (as well as those suffering miscarriages), (b) contraception, and (c) IVF. ${ }^{110}$

\section{A. IMMEDIATE IMPACT}

The immediate legal impact that Measure 26 would (or could) have had was never clear, in part because the language of the amendment was silent in this regard. ${ }^{111}$ For instance, it is possible that as soon as the amendment became effective, thousands of references in the Mississippi Code to "person" or "persons," including in homicide statutes, would have needed to be understood to include every human being from the moment of fertilization, cloning, or the functional equivalent thereof. In such a case, Measure 26 would have been effectively self-executing, since no enabling legislation would have been needed to set it in motion. ${ }^{112}$ Abortion becomes immediately problematic, because the existing statutory framework includes laws criminalizing the intentional killing of persons. Indeed, any loss of life

${ }^{105} I d$.

${ }^{106}$ See, e.g., Electa Draper, Personhood USA Again Pushes for Right-to-Life Amendment to Colorado Constitution, DENVER POST, Nov. 22, 2011, http://www.denverpost.com/news/ci_19387552 (noting that similar efforts would be pursued in Oregon and Montana); Stephanie Samuel, New Colo. Personhood Amendment Features New, Improved Language, Christian Post, Nov. 22, 2011, http:/www.christianpost.com/news/new-colo-personhood-amendment-features-new-improvedlanguage-62627/.

${ }^{107}$ Samuel, supra note 106.

${ }^{108}$ See infra Appendix I for the text of the new language that was proposed in Colorado. Part III briefly outlines the central debates in Mississippi, and also introduces the revisions made to the personhood language in response thereto. Part IV then discusses in detail the revisions pertaining to contraception and IVF, and why those revisions do not adequately address the primary concerns raised regarding reproductive choice.

109 Samuel, supra note 106.

${ }^{110}$ See generally Cohen \& Will, supra note 92; Will, Measure 26, supra note 81; Will, Life and Law, supra note 93 (discussing these questions). The University of Mississippi School of Law published a useful symposium related to Measure 26. Mississippi Personhood and Initiative 26 Symposium, 81 MISS. L.J. SUPRA i (2011), available at http://mississippilawjournal.org/category/volume-81/supra-volume-81/.

${ }^{111}$ See Cohen \& Will, supra note 92.

${ }^{112} \mathrm{Id}$. 
of these newly recognized persons could be investigated and prosecuted using the existing statutory framework. ${ }^{113}$

On the other hand, it is also possible that the amendment would have been interpreted to require enabling legislation to set it in motion, in which case, the amendment itself would have had no immediate impact (on abortion or otherwise). ${ }^{114}$ Under this scenario, after passage, discussions would have been held regarding what the enabling legislation should look like, and certainly an antiabortion statute would have been expected. ${ }^{115}$ But supporters of Measure 26 did not express consistent positions regarding whether the amendment was intended to be effectively self-executing. ${ }^{116}$

For instance, some proponents of the amendment suggested that Measure 26 merely set forth constitutional principles, and that it would need enabling legislation. ${ }^{117}$ At a symposium hosted by Mississippi College School of Law that I helped to organize in advance of the November election, the General Counsel of Liberty Counsel, which defended Measure 26 in legal challenges in Mississippi courts, suggested that the proposed amendment would require enabling legislation to be effective; however, at the same symposium, a national spokeswoman for Personhood USA indicated that she believed that after the amendment became effective, local prosecutors would immediately be permitted to decide whether to conduct investigations involving the loss of life of these newly recognized persons. ${ }^{118}$

As Professor Borgmann pointed out, many supporters of Measure 26, who thought they were voting on an abortion ban, may have been surprised if the amendment passed and yet had no immediate impact. ${ }^{119}$ And because Measure 26 failed, the Mississippi Supreme Court never had to address the question of whether, under state law, the amendment would have been effectively self-executing. In response to the uncertainty raised in Mississippi on this issue, the revised personhood language that was proposed in Colorado and elsewhere explicitly states that "all provisions [of the amendment] are self-executing and are severable."120

The significance of this position should not be lost. With no need for legislation to be enacted, these proponents seem to be suggesting that no discussion need be had

${ }^{113}$ Will, Measure 26, supra note 81, at 70-74; see also Deborah Bell, Disputes Over Frozen Embryos, 81 Miss. L.J. SUPRA 105, 113 (2011) (suggesting that courts, when confronted with disputes over dispositions of embryos, would be unlikely to ignore the "strong statement of policy" contained in Measure 26 when determining how to apply existing law).

${ }^{114}$ See Christopher R. Green, A Textual Analysis of the Possible Impact of Measure 26 on the Mississippi Bill of Rights, 81 Miss. L.J. SuPRA 39, 41 (2011) (considering whether Measure 26 could have outlawed abortion in Mississippi on its own).

${ }^{115}$ See Cohen \& Will, supra note 92.

${ }^{116} \mathrm{Id}$.

${ }^{117}$ See Caitlin E. Borgmann, What the Mississippi Personhood Amendment Tells Us About "Life," 81 Miss. L.J. SUPRA 115, 117 (2011); see also Memorandum from the Liberty Counsel to the Personhood Amendment Physicians' Working Grp. \& Other Interested Parties 1 (Sep. 17, 2011), http://yeson26.net/media/2455/personhoodphysiciansworkinggroupcivillawmemo.pdf.

${ }^{118}$ Stephen Crampton \& Rebecca Kiessling, Address at the Mississippi College School of Law Symposium: Amendment 26-Exploring the Implications of Mississippi's Personhood Initiative (Oct. 25, 2011). For descriptions of panelists' comments, see Debating Mississippi's "Personhood Amendment," CBS NEws, Oct. 26, 2011, http://www.cbsnews.com/8301-201_16220126236/debating-mississippis-personhood-amendment/; Valerie Wells, Personhood: A Pandora's Box, JACKSON Fre $\quad$ PRESS, $\quad$ Nov. 2011 , http://www.jacksonfreepress.com/news/2011/nov/02/personhood-a-pandoras-box/ 2, (describing panelists comments during the Symposium).

${ }^{119}$ Borgmann, supra note 117 , at 117.

${ }^{120}$ See infra Appendix I. 
by elected officials regarding the nature and scope of the amendment. Rather than subsequent political discussion defining the impact of the amendment on such things as abortion, the treatment of pregnant women, contraception or IVF, the amendment itself would dictate that the existing statutory framework is capable of dealing with these issues taking into account the new definition of the term "person." 121 Just as abortion would immediately become problematic, so too would the treatment of pregnant women, contraception, and IVF that involve the death of newly recognized persons. The existing statutory framework would treat these deaths just like any other loss of human life.

That said, the amendment's identifying itself as self-executing would not likely end the inquiry. When this revised language was recently introduced in Arkansas, the attorney general noted in his opinion rejecting the proposal that, given the changes that would be needed to the Arkansas Code if the proposal were to pass, the amendment could not be self-executing. ${ }^{122}$ Whether a given personhood amendment could be self-executing is a matter of individual state law ${ }^{123}$-an exploration of which is beyond the scope of this article. The revised language, however, makes clear that certain proponents have officially taken the position that they intend these amendments to have an immediate impact should they pass without further political discourse.

A different approach was taken recently in North Dakota. There, the State Senate approved a personhood initiative to amend the state constitution to add a very short statement protecting human life at any stage of development; ${ }^{124}$ however, a piece of enabling legislation (S.B. 2302) dealing with such things as birth control and IVF was simultaneously proposed in the Senate to take effect if the constitutional amendment is approved by the citizens of North Dakota. ${ }^{125}$ While S.B. 2302 was struck down by the Senate, since the constitutional initiative was approved by the House, it will appear on the ballot in 2014. ${ }^{126}$ And if the constitutional amendment passes, the North Dakota legislature is likely to revisit the implications for birth control and IVF. ${ }^{127}$

But if adoption of a personhood amendment is intended to have an immediate impact on the existing statutory framework without the need for enabling legislation, as it could in some states, what would that mean for the treatment of pregnant women, contraception, and IVF (question two from above)? Part IV of this article will focus on implications for reproductive choice, including contraception and IVF, but a few words on the treatment of pregnant women and miscarriages are in order.

${ }^{121}$ Further, certain existing laws pertaining to the preborn would become redundant at best, or unconstitutional at worst. There would be no need for specific feticide statutes, because fetuses would be treated no differently (save for proposed exceptions in the personhood amendment itself) than any other person. In fact, to treat the death of a fetus differently could raise equal protection issues under the Fourteenth Amendment, just as it would if we treated the death of toddlers differently than that of teenagers or adults. It would seem to be a violation of the equal protection of the toddler if the law were written to say that the unintentional killing of a toddler is not prohibited, or that the killing of a toddler is punishable by a maximum of only two years in prison. This is not to say that the Court would be precluded from determining that a fetus is sufficiently different than a born person so as to permit different treatment.

${ }^{122}$ Ark. Att'y Gen. Op., supra note 19.

${ }^{123}$ See generally Will, Measure 26, supra note 81.

${ }^{124}$ See Bassett, Senate, supra note 21.

125 See S.B. 2302, 63d Legis. Assemb., § 13 (N.D. 2013), available at http://www.legis.nd.gov/assembly/63-2013/documents/13-8231-02000.pdf?20130213153739.

${ }^{126}$ Bassett, House, supra note 21

${ }^{127}$ See infra Parts III \& IV. 


\section{B. TREATMEnT OF PREgnant WOMEn AND MiscarRiages}

With regard to treating pregnant women, the question pertains to whether recognizing fertilized ova (however fertilization is to be defined) ${ }^{128}$ as having the same legal status as pregnant women restricts the treatment options available for pregnant women. The most common concern raised in the media-in particular by physicians-involved the treatment of women with ectopic or molar pregnancies, which can prove life-threatening for pregnant women, and necessarily requires termination of the pregnancies. ${ }^{129}$ Some suggested that treating pregnant women in such cases could lead to civil or criminal penalties if Measure 26 were to pass. ${ }^{130}$

Perhaps not surprisingly, those within the Personhood Movement labeled such concerns as false information and scare tactics. ${ }^{131}$ Dr. Freda Bush, a vocal personhood proponent and Mississippi obstetrician, was comfortable that existing Mississippi laws would protect physicians treating pregnant women in emergency situations, but Dr. Paul Seago, a gynecologic oncologist in the State Capital, was concerned about treatments for women with cancer, many of which would endanger the fetus. ${ }^{132}$ At the time, Keith Mason's wife Jennifer, who serves as the communications director of Personhood USA, conceded that abortion would not be permitted for women with cancer. ${ }^{133}$

In Mississippi, certain statutes dealing with justifiable ${ }^{134}$ or excusable ${ }^{135}$ homicide would arguably have been available to defend physicians treating pregnant women in these circumstances. ${ }^{136}$ The United States Supreme Court has also referenced the principle of double effect when considering situations in which death occurs as a foreseen though unintended consequence of otherwise permissible activity. 137 "Out of an abundance of caution," however, Liberty Counsel suggested in a legal memorandum pertaining to Measure 26, that it would be "in favor of enabling legislation explicitly providing immunity to medical professionals who unintentionally caused the injury or death to the unborn child during treatment of the mother for an ectopic pregnancy or other life-threatening situations, as well as those

\footnotetext{
${ }^{128}$ See infra Part IV.

129 See Rob Mank, Doctors Call Mississippi "Personhood" Initiative Dangerous, CBS NEwS, Nov. 4, 2011, http://www.cbsnews.com/8301-503544_162-57318625-503544/doctors-call-mississippipersonhood-initiative-dangerous/ (discussing ectopic pregnancies (those where implantation occurs outside the uterus), and molar pregnancies (where the fertilized egg becomes an abnormal growth instead of a fetus), each of which will not lead to successful pregnancies, but can cause the woman to bleed to death or suffer other "dire consequences").

${ }^{130}$ Laura Bassett, Mississippi 'Personhood' Law Could Cause Legal Mayhem, Experts Warn, HUFFINGTON POST (Nov. 7, 2011), http://www.huffingtonpost.com/2011/11/07/mississippipersonhood-la n 1079710.html.

${ }^{131}$ Denise Grady, Medical Nuances Drove 'No' Vote in Mississippi, N.Y. Times, Nov. 14, 2011 , http://www.nytimes.com/2011/11/15/health/policy/no-vote-in-mississippi-hinged-on-issues-beyondabortion.html?pagewanted=all.

${ }^{132} I d$.

${ }^{133} \mathrm{Id}$.

${ }^{134}$ Miss. Code ANN. § 97-3-15 (West 2011).

${ }^{135}$ Id. $\S 97-3-17$.

${ }^{136}$ See Geroge S. Whitten, Jr. \& Jameson Taylor, Personhood Amendment Will Not Change Legal Safeguards for Physicians Providing Necessary Treatment to Pregnant Patients, MISS. CTR. FOR PUB. POL'Y, http://www.mspolicy.com/downloads/Initiative26Analysis.pdf (last visited Oct. 1, 2013).

${ }^{137}$ See Vacco v. Quill, 521 U.S. 793, 808 n.11 (1997) (noting that informed consent and the principle of double effect could be utilized by a state to permit palliative care-specifically referencing terminal sedation- "which may have the foreseen but unintended 'double effect' of hastening the patient's death").
} 
involved with in vitro fertilization who do not recklessly or intentionally destroy living human beings." 138

Of course, if the personhood amendments now being proposed are selfexecuting, then no enabling legislation is needed. Since this means that the scope of, or exceptions to, the amendment would not need to be delineated by subsequent legislation, as a matter of immediacy, any limitations on the language should be included in the amendment itself. After the failure of Measure 26 then, Personhood USA went ahead and revised the language to include certain exceptions. ${ }^{139}$

Specifically, the new language states that while "the intentional ${ }^{140}$ killing of any innocent person is prohibited ... medical treatment for life threatening physical conditions intended to preserve life shall not be affected by this section," where such medical treatment includes, but is not limited to, "treatment for cancer, ectopic and molar pregnancy, twin-to-twin transfusion syndrome, and placenta previa." 141 "Lifethreatening" is not defined in these revisions, ${ }^{142}$ which creates lingering questions. For instance, it is unclear whether termination of a pregnancy would be permissible if a woman with cancer could potentially survive without chemotherapy until the fetus became viable (followed by a Caesarian section, as suggested by Jennifer Mason). ${ }^{143}$ For purposes here, it is sufficient to note that personhood proponents have at least attempted to add some immediate protection for physicians treating pregnant women given that the amendment is intended to have an instant impact if passed. ${ }^{144}$

It is also worth mentioning the concerns identified regarding women experiencing miscarriages. Under a personhood framework a miscarriage results in the death of a person, and normally, loss of human life is followed by an investigation into the cause, regardless of whether charges ultimately get filed. ${ }^{145}$ Personhood proponents identified these concerns as the further use of scare tactics, and Dr. Freda Bush suggested that police would not have time for such "witch hunts." ${ }^{\prime 146}$ Personhood USA's poll did not indicate that investigation of miscarriages was a prominent reason for the defeat of Measure $26,{ }^{147}$ but nevertheless, the new personhood language includes the statement that "spontaneous miscarriages shall not

\footnotetext{
${ }^{138}$ Memorandum from Liberty Counsel, supra note 117, at 5. For more on IVF see infra Parts III and IV.

${ }^{139}$ See infra Appendix I.

${ }^{140}$ Intent is not defined. It may be that the amendment itself solely implicates situations where there is a "determination" to kill (specific intent), but in the criminal context in particular, general intent can take "the form of recklessness (involving actual awareness of a risk and the culpable taking of that risk) or negligence (involving blameworthy inadvertence)." BLACK'S LAW DICTIONARY 881-82 (9th ed. 2009). This is important given our awareness of the risks associated with taking certain forms of birth control or undertaking certain procedures in IVF. See infra Part IV. Even if the amendment itself is considered not to immediately impact certain activities or circumstances (due to a lack of specific intent) it at least creates a framework in which subsequent restrictions could be enacted by proponents wishing to remain consistent with the personhood position. See infra notes 151-57 and accompanying text.

${ }^{141}$ See infra Appendix I.

${ }^{142}$ See id.

${ }^{143}$ Grady, supra note 131. This issue received national attention recently when a pregnant teenager with leukemia in the Dominican Republic died after being denied chemotherapy. See, e.g., Raphael Romo, Dominican Republic Abortion Ban Stops Treatment for Pregnant Teen with Cancer, CNN (Jul. 25, 2012), http://www.cnn.com/2012/07/25/world/americas/dominican-republic-abortionteen/index.html.

${ }^{144}$ See Whitten \& Taylor, supra note 136.

${ }^{145}$ Will, Life and Law, supra note 93.

${ }^{146}$ Grady, supra note 131.

${ }^{147}$ See Ashley, supra note 100.
} 
be affected by this section," where "spontaneous miscarriage" is defined as "the unintentional termination of a pregnancy." 148

Because miscarriage is here defined in terms of pregnancy, the revision may reflect the common understanding that naturally-occurring fertilization is generally undetectable until the implantation process is complete, which is commonly considered to mark the onset of pregnancy. ${ }^{149}$ This may suggest that there should be no investigation into the greater than fifty percent of fertilized ova that are naturally expelled from a woman prior to implantation, ${ }^{150}$ notwithstanding the fact that under a personhood framework, a human life has been lost.

But beyond this, the revision does not address the normative problem, which is whether under a personhood framework, women known to be pregnant who experience miscarriages would (or ought) be investigated in connection with that loss of human life. After all, how would the intent with which the pregnancy was terminated be determined save for an investigation? A pregnant woman may look forward to parenthood, but may continue to take narcotics during pregnancy because she is addicted. Any miscarriage would appear to be unintentional (at least lacking specific intent), and perhaps spontaneous under the revised language. Or she may specifically intend that the drug use will lead to the termination of her pregnancy. Even if the authorities, after inquiry, plan to take her word regarding intent, an investigation would seem quite necessary. Importantly, whether such investigation would lead to a prosecution is a separate, but related question.

The issue of drug use during pregnancy raises another problem with the revised language that I will identify here but leave for others to address. Imagine a situation where a state has a statute that permits a woman to be prosecuted and sent to prison for twenty years if she has a miscarriage (even if unintentional) caused by drug use. ${ }^{151}$ Or consider Rennie Gibbs who, without regard to any personhood amendment, was charged in 2011 with depraved-heart murder in Mississippi ${ }^{152}$ when she experienced a stillbirth at thirty-six weeks gestation, and it was discovered that she had a cocaine habit. ${ }^{153}$ If these miscarriages were determined to be unintentional, would such prosecutions be permissible if a state constitutional provision provided that any unintentional termination of pregnancy is not prohibited by the amendment itself?

It is unlikely that a drug-induced miscarriage would be considered acceptable by personhood proponents under the revised personhood language regardless of whether the woman intended for the pregnancy to terminate. ${ }^{154}$ In response to

\footnotetext{
${ }^{148}$ See infra Appendix I.

${ }^{149}$ See Elizabeth Spahn \& Barbara Andrade, Mis-Conceptions: The Moment of Conception in Religion, Science, and Law, 32 U.S.F. L. REV. 261, 294 n.205 (1998).

${ }^{150}$ Michael J. Sandel, Embryo Ethics: The Moral Logic of Stem-Cell Research, 351 NEw ENG. J. MED. 207, 208 (2004). Some studies suggest that $75 \%$ to $80 \%$ of pre-embryos or embryos die in early pregnancy. COHEN, supra note 51 , at 65.

${ }^{151}$ In South Carolina a woman was sentenced to twenty years in prison after experiencing a stillbirth found to be caused by drug use. See State v. McKnight, 576 S.E.2d 168 (S.C. 2003).

${ }^{152}$ Miss. CODE ANN. § 97-3-19 (West 2011).

${ }^{153}$ See, e.g., Ed Pilkington, Outcry in America as Pregnant Women Who Lose Babies Face Murder Charges, GuARDIAN, June 24, 2011, http://www.guardian.co.uk/world/2011/jun/24/americapregnant-women-murder-charges. After initially accepting an interlocutory appeal to decide the issue, the Mississippi Supreme Court determined that Ms. Gibbs would have to stand trial before the Court would determine whether the law applied to pregnant women. See Gibbs v. State, No. 2010-IA-00819SCT, Order No. 172566 (Miss. Oct. 27, 2011) (order dismissing interlocutory appeal), available at http://courts.ms.gov/Images/Orders/700_61759.pdf.

${ }^{154}$ See Ada Calhoun, The Criminalization of Bad Mothers, N.Y. Times MAG. (Apr. 25, 2012), http://www.nytimes.com/2012/04/29/magazine/the-criminalization-of-bad-
} 
Alabama's chemical endangerment statute, Ben Dupré, the director of Personhood Alabama, was quoted as saying that "I think it would be unequal protection to give the woman a pass when anyone else who injects drugs into a child would be prosecuted." 155 One critic of Alabama's statute suggested that it is a "personhood measure in disguise." 156

Perhaps then, Personhood USA intends that while the amendments themselves may not be considered to prohibit unintentional miscarriages, existing statutes are available to prosecute women experiencing them. ${ }^{157}$ If that is the case, then the revised language addresses none of the issues raised in the Mississippi debates. It is unexceptional that personhood proponents would not condone drug use by pregnant women, but what other activities should be considered problematic? If a physician tells a woman to refrain from certain activities while pregnant, but she engages in them anyway and experiences a miscarriage (regardless of intent), would those women be subject to investigation or prosecution under the existing statutory framework? If proponents are committed to the protection of the unborn, it is unclear why they would consider such investigations to be "witch hunts." The revised personhood language does not appear to provide any protection in this regard, and raising the possibility of investigation into miscarriages may not be fear mongering or the use of scare tactics after all.

\section{IMPLICATIONS FOR CONTRACEPTION AND/OR IN VITRO FERTILIZATION?}

In the weeks leading up to the vote in Mississippi, a great deal of attention (and confusion) ${ }^{158}$ surrounded what impact, if any, Measure 26 would have on contraception and/or IVF. ${ }^{159}$ Personhood opponents suggested that the amendment would outlaw contraception and IVF, while proponents fired back that anyone raising these concerns was simply engaging in fear mongering or the use of scare tactics. ${ }^{160}$ Neither claim was entirely accurate. With no certainty regarding the immediate impact of Measure 26 were it to have passed, assertions that the amendment would definitely outlaw contraception or IVF were not correct. Similarly, given the inconsistent statements made within the Personhood Movement

mothers.html?pagewanted=all (noting the relationship between chemical endangerment laws (like seen in Alabama that are used to prosecute pregnant drug users) and the Personhood Movement). The trend of criminally prosecuting pregnant women in similar circumstances is growing. See Pilkington, supra note 153. For a general discussion of the rise of criminal and civil statutes regarding harm caused to the preborn, see Brown, supra note 5, at 90-97.

${ }^{155}$ Pilkington, supra note 153.

${ }^{156} \mathrm{Id}$.

${ }^{157}$ In a recent interview Keith Mason maintained that claims made about miscarriages by opponents are ridiculous, but went on to note that "I know of cases where a woman that is addicted to crack will have her baby and the state will take the crack baby away because of child abuse and mandate the woman receive treatment-I'm good with that." Pesta, supra note 41.

${ }^{158}$ See Borgmann, supra note 117 , at $117 \mathrm{n} .13$.

${ }^{159}$ For a discussion of the potential implications for contraception and IVF, see, e.g., Grady, supra note 131; Will, Measure 26, supra note 81.

${ }^{160}$ See, e.g., Borgmann, supra note 117, at 117; Mandi D. Campbell, Reviving a Culture of Life in America, 6 LiBerTy U. L. REV. 283, 296 (2012) (stating that "in past personhood debates, proabortion groups and individuals told people that the personhood amendments would make birth control and in-vitro fertilization illegal and engaged in other fear-mongering tactics that scared people away from choosing life"); Will, Measure 26, supra note 81, at 64 . 
regarding contraception and IVF, ${ }^{161}$ it was disingenuous for proponents of the amendment to claim that raising these concerns was simply resorting to scare tactics.

With respect to those proponents claiming that Measure 26 would need enabling legislation, it was technically truthful, though perhaps misleading, for them to say that the amendment itself would not outlaw contraception or IVF. ${ }^{162}$ Misleading, because if the amendment passed, it would leave open the possibility that the subsequent enabling legislation would do just that. In fact, different proponents appeared to have different views about the potential and intended impact of the amendment on things like contraception and IVF. ${ }^{163}$

It was clear that abortifacients like RU-486 that cause the embryo or fetus to detach from the uterine wall and then be expelled from the body ${ }^{164}$ would be problematic, as would emergency contraception (such as Plan B, the "morning after pill") ${ }^{165}$ or intrauterine devices (IUDs) that are thought to prevent implantation of a fertilized egg, but views considering standard hormonal contraceptives became more opaque. ${ }^{166}$ Likewise, while proponents consistently maintained that unused preembryos from an IVF cycle could not be discarded or destroyed, they were less transparent about their intent regarding specific aspects of the IVF process that create risk of harm to pre-embryos, like cryopreservation and the transfer process itself. ${ }^{167}$ Some personhood proponents will openly express discomfort with current IVF practices, ${ }^{168}$ but a Mississippi attorney and "Yes on 26 " spokesman was adamant in his view that Measure 26 would not outlaw (or presumably significantly restrict) IVF. ${ }^{169} \mathrm{He}$ publicly discussed his own two children conceived with the assistance of IVF, and stated that IVF would not be banned by the measure. ${ }^{170}$

The revised personhood language attempts to put these issues to rest with two seemingly straightforward provisions. While "the intentional killing of any innocent person is prohibited," (1) "only birth control that kills a person" and (2) "only in vitro fertilization and assisted reproduction that kills a person" are affected by the section. ${ }^{171}$ The remainder of this paper now turns to whether the concerns raised regarding contraception and IVF were legitimate (or just fear mongering), and whether the revised language used within the Personhood Movement addresses them.

${ }^{161}$ See, e.g., Irin Carmon, The Next Front in the Abortion Wars: Birth Control, SALON (Oct. 26, 2011), http://www.salon.com/2011/10/26/the_next_front_in_the_abortion_wars_birth_control/.

${ }_{162}$ See Will, Measure 26, supra note 81, at 66-70.

${ }^{163}$ See, e.g., Carmon, supra note 161.

${ }^{164}$ E.g., Jennifer E. Spreng, Pharmacists and the "Duty" to Dispense Emergency Contraceptives, 23 Issues L. \& MED. 215, 225 (2008).

165 "Morning after pill" is not an entirely accurate description since emergency contraception can effectively prevent pregnancy if taken within 72 hours of unprotected sexual intercourse. Id. at 222. For a discussion of the debates regarding the mechanisms of operation of emergency contraception, see infra notes 196-205 and accompanying text.

${ }^{166}$ See, e.g., Grady, supra note 131.

${ }^{167} \mathrm{Id}$.

${ }^{168}$ In a recent interview, Keith Mason acknowledged that the Personhood Movement seeks to regulate reproductive technology, noting that the Movement "has exposed some of the dark secrets of the IVF industry." John Keilman \& Melissa Jenco, 'Personhood' Becomes Ground for Debate in Naperville, CHI. TRIB., Apr. 5, 2012, http://articles.chicagotribune.com/2012-04-05/news/ct-metnaperville-fertilty-clinic-follo-20120405_1_ralph-kazer-ivf-fertilization.

${ }^{169}$ Carmon, supra note 161.

${ }^{170} \mathrm{Id}$.

${ }^{171}$ See infra Appendix I. 


\section{NEW LANGUAGE-SAME CONCERNS REGARDING REPRODUCTIVE CHOICE}

Recall that Measure 26 defined "person" with reference to fertilization, cloning, or the functional equivalent thereof. ${ }^{172}$ Under the revised language the term is defined to apply "to every human being regardless of the method of creation," where "human being" means "a member of the species [H]omo sapiens at any stage of development." 173 This change was likely a response to those who pointed out that the use of "fertilization" in Measure 26 was ambiguous, because it could refer to several different moments in the early reproductive process ranging from when the sperm penetrates the egg to successful implantation, which occurs as much as two weeks later. ${ }^{174}$

Personhood USA is clear that it intends the rights and privileges associated with personhood to attach as early as possible in the reproductive process. On its website, instead of a reference to successful implantation, you find "[the zygote] formed by the union of an oocyte [egg] and a sperm [as] the beginning of the new human being." 175 That said, "union of egg and sperm" is not the language used in the revised amendments; nor should it be for at least two reasons. First, we now know that the union of the genetic material in the egg and sperm itself is a process taking some 48-72 hours to complete. ${ }^{176}$ Within this time period, the sperm penetrates the egg, the maternal and paternal genetic material aligns, and then the new genome activates. ${ }^{177}$ Using the phrase "any stage of development" is presumably an attempt to select the earliest possible moment without the need to distinguish among these developmental landmarks. Indeed, some have argued that human development begins "when the egg and sperm have met." ${ }^{178}$ Second, the revised language continues to allow cloned human beings to be included in the definition of "person," sperm. ${ }^{180}$

It is worth noting, though I will not belabor here, that the lack of reference to biological landmarks should not prove satisfying for those who believe that these

\footnotetext{
${ }^{172}$ Will, Measure 26, supra note 81, at 63.

${ }^{173}$ See infra Appendix I.

${ }^{174}$ See, e.g., Cohen \& Will, supra note 92 (citing Philip G. Peters, Jr., The Ambiguous Meaning of Human Conception, 40 U.C. DAVIS L. REV. 199, 200-04 (2009)).

${ }^{175}$ What is Personhood, supra note 29 (citing Keith L. Moore, The Developing Human: Clinically ORIEnTEd EMBRyology 2, 16 (7th ed. 2003)).

${ }^{176}$ Peters, supra note 174 , at 205-15.

${ }^{177} \mathrm{Id}$.

${ }^{178} I d$. at 206 n.21. See supra notes 44-47 and accompanying text (discussing alternative moments when membership in the human species could be designated to begin). Further insight can be garnered from the Federal Sanctity of Human Life Act, which was re-introduced in January 2013. See Sanctity of Human Life Act, H.R. 23, 113th Cong. (2013) (declaring that the right to life guaranteed by the Constitution begins with "fertilization, cloning, or its functional equivalent," where fertilization is further defined to mean "the process of human spermatozoan penetrating the cell membrane of a human oocyte to create a human zygote, a one-celled human embryo, which is a new unique human being"). While this definition does not reference our more nuanced understanding of reproductive physiology, by attaching personhood prior to the first cellular cleavage, it would place the persondefining moment within the first twenty-four hours after the sperm penetrates the egg. Peters, supra note 174 , at 210 n.36.

${ }^{179}$ See supra Part II.

${ }^{180}$ The process of cloning, or somatic cell nuclear transfer, involves removing the nucleus of an egg cell, replacing it with the genetic material of an adult cell, and then stimulating the re-nucleated cells to divide. Elizabeth Price Foley, Human Cloning and the Right to Reproduce, 65 ALB. L. REV. $625,626(2002)$.
} 
distinctions are meaningful. Even if the rights and privileges associated with legal personhood are meant to attach at the very beginning of biological life-as opposed to using some "thicker" conception of life ${ }^{181}$ — we ought to be clear about when this "thin" notion of biological life actually begins. Importantly, personhood proponents are attempting to avoid the slippery slope involved in discussions about "potential life," and when there is sufficient "potential" to be worthy of constitutional protection. ${ }^{182}$ But it is not clear from the revised language when development of a living member of the Homo sapiens species begins, ${ }^{183}$ and it would not seem appropriate to accord full constitutional protection to non-living members.

For example, until genomic activation occurs, the pre-embryonic genome is dormant, as it lacks its own mitochondrial DNA (the cellular engine) to drive development. ${ }^{184}$ One could argue that until the genome has its own power source (via genomic activation - the timing of which is still not well understood), we do not have a living member of the Homo sapiens species. ${ }^{185}$ Genomic activation could occur as late as the 100-cell stage (which would be several days after either the sperm penetrates the egg or re-nucleation). ${ }^{186}$ Therefore, making this distinction would have drastic impacts on the permissibility of certain activities within the IVF process, since no life would be lost unless occurring after genomic activation. ${ }^{187}$ In addition, for those who find meaning in the concept of individual genetic identity (numeric or otherwise) as it relates to defining members of the Homo sapiens species, further discussion could be had regarding genomic alignment, cell differentiation, and/or the process of twinning. ${ }^{188}$

But for purposes here it will be assumed that the revised language intends for the rights and privileges of personhood to attach very shortly after the sperm penetrates the egg (or the egg is re-nucleated in the context of cloning); that is, within the first twenty-four hours, and prior to the first cellular cleavage. ${ }^{189}$ This is significant because the earlier in the reproductive process that rights attach, the greater the implications for reproductive choice.

\section{A. PERSONHOOD AND CONTRACEPTION}

The concern raised in regard to prior iterations of personhood measures was that birth control methods that are effective in preventing successful pregnancy after the sperm has penetrated the egg could be problematic, since "such birth control

\footnotetext{
${ }^{181}$ See supra notes 2, 41-51 and accompanying text.

${ }^{182}$ See, e.g., Will et al., supra note 48; R. Albert Mohler, Jr., We're All Harry Blackmun NowThe Lessons of Mississippi, Christian Post (Nov. 19, 2011), http://www.christianpost.com/news/were-all-harry-blackmun-now-the-lessons-of-mississippi-62422/ (stating that "unless the unborn child is recognized as a person at every point in its development, we are just negotiating our own arbitrary definition of human personhood and human life").

${ }^{183}$ See infra Appendix I.

${ }^{184}$ Peters, supra note 174 , at 212.

${ }^{185}$ See id. at 227.

${ }^{186} \mathrm{Id}$. at $212-13$.

${ }^{187} \mathrm{Id}$. at 218 .

${ }^{188}$ See, e.g., id. at 218.; Will et al., supra note 48, at 39-40; COHEN, supra note 51, at 66-68.

${ }^{189}$ Peters, supra note 174, at 205-212. Arguably, the process of development begins as soon as the sperm attaches to the egg, since structural changes occur to both the sperm and egg to allow penetration and subsequent genomic alignment. Id. The Catholic Church appears to have settled on the fusion of the male and female gametes as the beginning of human life, which occurs many hours after the sperm penetrates the egg. Id. at 225. In the context of cloning, clinicians would have to stimulate the re-nucleated cell to initiate cellular division, whereas this process begins naturally when the sperm penetrates the egg. Id. at 205-212.
} 
methods permit (or at least potentially permit) a person to come into existence, and then effectively and intentionally ensure that person's ultimate demise." ${ }^{190}$ It was clear in Mississippi that barrier forms of contraception like condoms and spermicides that prevent the sperm from reaching or penetrating the egg would not be implicated. ${ }^{191}$ On the other hand, personhood proponents openly condemned IUDs, emergency contraception, and RU-486, since each of these are thought to be effective after the sperm has penetrated the egg, either by preventing successful implantation of the fertilized ovum, or by causing the pregnancy to terminate after implantation has occurred. ${ }^{192} \mathrm{Up}$ for debate was the intended (or potential) impact of personhood on hormonal contraceptives that are used by many women in the United States. ${ }^{193}$

The revised language does nothing to clarify the stance of personhood proponents when it comes to hormonal contraception. ${ }^{194}$ Eliminating the word fertilization from the definition of "person" does not address the issue-nor does inclusion of the statement that only birth control that "kills a person" is prohibited. When pressed, Keith Mason recently explained that he is "not opposed to contraception," just "methods that "kill a living human being." ${ }^{195}$ But that is precisely the concern associated with hormonal contraceptives, which are effective by using the same mechanisms of operation utilized in what personhood proponents find clearly problematic —emergency contraceptives like Plan B. ${ }^{196}$

Just briefly, hormonal contraceptives (including emergency contraception) ${ }^{197}$ have been thought to utilize multiple mechanisms of operation to prevent pregnancy:

\footnotetext{
${ }^{190}$ Will, Measure 26, supra note 81 , at 67.

${ }^{191} \mathrm{Id}$. at $66 \mathrm{n} .16$.

${ }^{192}$ Thaddeus Mason Pope, Legal Briefing: Conscience Clauses and Conscientious Refusal, $21 \mathrm{~J}$ Clinical Ethics, 163, 166 (2010).

${ }^{193}$ A 2010 study performed by the Centers for Disease Control and Prevention (CDC) showed that through 2008, hormonal contraceptives (including the "pill," patches, implants, injections, and vaginal rings), were by far the most common form of non-permanent birth control used by women, with the pill clearly being the most dominant. Ctr. for Disease Control \& Prevention, Use of Contraception in the United States: 1982-2008, 23 Vital \& Health Stats. 29 (Aug. 2010), http://www.cdc.gov/nchs/data/series/sr_23/sr23_029.pdf; see also CONTRACEPTIVE USE IN THE UNITED STATES, GUTTMACHER INST. (Aug. 2013), available at
} http://www.guttmacher.org/pubs/fb_contr_use.html.

${ }^{194}$ See infra Appendix I.

${ }^{195}$ Pesta, supra note 41 . The enabling legislation that was to accompany the recently proposed constitutional amendment in North Dakota similarly would have outlawed "birth control that can be clinically proven to kill a person," and the state department of health was tasked with providing a list of any such forms of contraception. See S.B. 2302, 63d Legis. Assemb., § 2(2)(a) (N.D. 2013), available at $\quad \mathrm{http}: / / w w w . l e g i s . n d . g o v / a s s e m b l y / 63-2013 /$ documents/13-823102000.pdf?20130213153739. But given the current status of our clinical understanding of the postfertilization effects of certain forms of birth control, it is unclear what that list might have looked like. See infra notes 197-204 and accompanying text.

${ }^{196}$ See, e.g., Rachel White-Domain, Making Rules and Unmaking Choice: Federal Conscience Clauses, the Provider Conscience Regulation and the War on Reproductive Freedom, 59 DEPAUL L. REV. 1249, 1260 (2010).

${ }^{197}$ There are different types of hormonal contraception and emergency contraception. The most common types of hormonal contraception are combined pills ("COCs," which contain both estrogen and progesterone), and progesterone-only pills (POPs). See, e.g., Walter L. Larimore, M.D., Growing Debate About the Abortifacient Effect of the Birth Control Pill and the Principle of Double Effect, 16 ETHICS \& MED. 23 (2000), available at http://www.epm.org/resources/2004/Oct/01/growing-debateabout-abortifacient-effect-birth-co/. Emergency contraception may involve the Yuzpe method (taking larger doses of daily oral contraceptive pills), or Plan B (a regimen of two doses of levonorgestrel taken twelve hours apart). Spreng, supra note 164, at 224-26. In addition, the FDA recently approved "Plan B One-Step," which involves a single dose of lovenorgestrel, and ulipristal acetate-based EC 
(1) preventing ovulation as an initial matter by suppressing pituitary gonadotropin secretion, which is the mechanism operative most of the time; (2) altering cervical mucus to limit sperm penetration; (3) altering the endometrium (uterine lining) and fallopian tube to impede sperm travel; and (4) altering the endometrium rendering it inhospitable to successful implantation. ${ }^{198} \mathrm{~A}$ woman who avoids pregnancy by taking hormonal contraception will not know which of these mechanisms worked. ${ }^{199}$ The pill (morning-after or standard) may have failed to prevent ovulation and failed to prevent the sperm from penetrating the egg, but nonetheless succeeded in preventing the fertilized ovum from implanting, which would lead to the death of this newly recognized person. ${ }^{200}$

Importantly, the true post-fertilization impact of hormonal contraceptives, including emergency contraceptives, is still hotly debated. ${ }^{201}$ To the extent these methods are found to be only effective prior to the sperm penetrating the egg, personhood ought to have no impact on the permissibility of such contraceptives. But assuming that these methods can be effective in preventing successful pregnancy post-fertilization (by preventing intrauterine implantation and/or causing a miscarriage), perhaps the most forthright response regarding personhood's intended impact comes from Bill Fortenberry, a prominent personhood advocate in Alabama. ${ }^{202}$

In his article Personhood and the Pill, Fortenberry wrote that to the extent hormonal contraception has an abortifacient effect, it would be banned by a personhood amendment. ${ }^{203} \mathrm{He}$ discussed research addressing whether hormonal contraception has such an effect, including one study that showed that twenty-one out of twenty-five women who became pregnant while on an oral hormonal contraceptive subsequently miscarried, which is twice the miscarriage rate for women not on the pill. ${ }^{204}$

(ella), which is effective up to 120 hours after intercourse. MARK R. WiCclair, COnSCIENTIOUS Objection in Health CARe 22 (2011).

${ }^{198}$ Walter L. Larimore, M.D. \& Joseph B. Stanford, M.D., Postfertilization Effects of Oral Contraceptives and Their Relationship to Informed Consent, 9 ARCH. FAM. MED. 126, 127-29 (2000).

${ }^{199} I d$.

${ }^{200}$ Will, Measure 26, supra note 81, at 69. Dr. Larimore notes that POPs and Norplant (a subcutaneously implanted progesterone rod) are more likely to be effective post-fertilization than COCs. Larimore, supra note 197. Indeed, some opponents to the "hostile endometrium theory" argue that the level of progesterone in COCs is too low to have the post-fertilization impact suggested, particularly given the changed hormonal environment that would exist if break-through ovulation should occur. Id.

${ }^{201}$ See Spreng, supra note 164, at 223; Michelle Castillo, Investigation Reveals Morning-After Pill May Not Prevent Implantation, CBS News (June 7, 2012), http://www.cbsnews.com/8301504763 162-57448998-10391704/investigation-reveals-morning-after-pill-may-not-prevent-

implantation/. Drs. Larimore and Stanford, on the other hand, cite to studies showing that hormonal contraception can alter the endometrium in a fashion that decreases the likelihood of successful intra uterine implantation. Larimore \& Stanford, supra note 198, at 128-29 (noting that hormonal contraceptives reduce the thickness of the endometrium, alter integrin expression, and also potentially increase the risk of extra-uterine implantation, such as ectopic pregnancies). Several studies have indicated that the risk of ectopic pregnancy is higher for women using POPs. Id. at 129. Dr. Larimore acknowledges, however, that there are opponents to the "hostile endometrium theory," and he admits that little direct evidence exists for the true post-fertilization impacts of hormonal contraception. Larimore, supra note 197.

${ }^{202}$ See Bill Fortenberry, Personhood and the Pill, Personhood Initiative, available at http://www.personhoodinitiative.com/personhood-and-the-pill.html (last visited Oct. 25, 2013)

${ }^{203} I d$.

${ }^{204} \mathrm{Id}$. Note that this is different from the question of which mechanism of operation makes the birth control method effective in preventing pregnancy. Here we are talking about the failure of the birth control to prevent pregnancy (successful implantation), yet nonetheless causing a subsequent 
Given the increased likelihood demonstrated in the study for hormonal contraception to lead to miscarriage (and the death of a person), Fortenberry explicitly concluded that the "Personhood Initiative will continue to advocate for a ban of any form of birth control that can be proven to cause the deaths of innocent children." ${ }^{205}$ While Mason can appear evasive when asked about contraception, Fortenberry's position is clearly consistent with the goal of the Personhood Movement to protect all innocent persons, where personhood is considered to attach within the first twenty-four hours after the sperm penetrates the egg. Following the loss in Mississippi, one personhood advocate-who expressly believes that the personhood movement would outlaw any type birth control that permits the fertilization of the egg-noted that, in voting down the amendment, some conservatives demonstrated that they "are not really so pro-life as [they] think.",206

The relationship between pre-embryonic personhood and contraception can also be seen in the debates surrounding conscience clause legislation in the healthcare context. ${ }^{207}$ These laws permit service providers and institutions to deny providing medical services on the basis of conscientious objection, and suggest that certain forms of birth control could be at risk of significant regulation under a personhood framework, even if the legislation or amendments that pass do not specifically impose them. ${ }^{208}$

At the federal level, in 2008 the Bush Administration pushed the Provider Conscience Regulation (PCR) in order to protect providers who refuse to perform certain actions based on conscience. ${ }^{209}$ The PCR attempted to define abortion ${ }^{210}$ "to include any action that prevents the implantation of a fertilized egg, effectively including the birth control pill, other hormonal contraceptives and the intrauterine device." ${ }^{211}$ The Obama Administration rescinded most of the PCR in $2011,{ }^{212}$ but

miscarriage. It is the increased risk of miscarriage that Fortenberry is identifying as being problematic. In other words, when the pill is successful (operating pre-fertilization), it may not be problematic under a personhood framework; however, it would still be problematic given the risk that the pill will fail to prevent pregnancy, yet nonetheless lead to miscarriage. Id.

${ }^{205} \mathrm{Id}$.

${ }^{206}$ Mohler, supra note 182. One survey suggested that the majority of American Catholics disagree with the Church's prohibitions on contraception. Elizabeth Sepper, Not Only the Doctor's Dilemma: The Complexity of Conscience in Medicine, 4 FaulKner L. ReV. 385, 399-400 (2013) (citing Catholics for Choice, In Good Conscience: Respecting the Beliefs of HealthCare PROVIDERS AND THE NEEDS OF PATIENTS 10 (2010)).

${ }^{207}$ For a comprehensive discussion of laws regarding freedom of conscience, see Nadia $\mathrm{N}$ Sawicki, The Hollow Promise of Freedom of Conscience, 33 CARdozo L. REV. 1389 (2012); for a discussion of the relationship between the Personhood Movement and conscience legislation, see Jonathan F. Will, Conscience Legislation, the Personhood Movement, and Access to Emergency Contraception, 4 FAULKNER L. REV. 411 (2013) [hereinafter Will, Conscience Legislation].

${ }^{208}$ See, e.g., Sawicki, supra note 207; Will, Conscience Legislation, supra note 207.

${ }^{209}$ White-Domain, supra note 196 , at $1250 \mathrm{n} .13$ (identifying the full name of the regulation as "Ensuring That Department of Health and Human Services Funds Do Not Support Coercive or Discriminatory Policies or Practices in Violation of Federal Law," which was located at 45 C.F.R $\S 88$ (2008) (rescinded by Regulation for the Enforcement of Federal Health Care Provider Conscience Protection Laws, 76 Fed. Reg. 9968-02 (Feb. 23, 2011)).

${ }^{210}$ The earliest conscience laws, like the Church Amendment, concerned abortion, and were enacted shortly after Roe v. Wade. See Pope, supra note 192, at 164.

${ }^{211}$ Adam Sonfield, Proposed 'Conscience' Regulation Opposed Widely as Threat to Reproductive Health and Beyond, 11 GUTTMACHER POL'Y REV. 4 (2008), available at http://www.guttmacher.org/pubs/gpr/11/4/gpr110417.html.

${ }^{212}$ Regulation for the Enforcement of Federal Health Care Provider Conscience Protection Laws, 76 Fed. Reg. at 9968-02; see also Rob Stein, Obama Administration Replaces Controversial "Conscience" Regulation for Health Care Workers, WASH. POST, Feb. 19, 2011, available at http://www.washingtonpost.com/wp-dyn/content/article/2011/02/18/AR2011021807443.html. 
recently proposed federal legislation would have offered even broader protection for conscientious objection, ${ }^{213}$ and individual states have also taken up this cause. ${ }^{214}$

Although conscientious objection to abortion has long been protected by most states, by the mid-2000s, states increasingly began to acknowledge objections to the provision of emergency contraception. ${ }^{215}$ Some states have expanded their conscientious objection protection in a way that would include any form of contraception. ${ }^{216}$ The Guttmacher Institute reports that as of August 2012 there are fourteen states that allow some healthcare providers to refuse to provide contraception, and six states explicitly permit pharmacists to refuse to dispense contraceptives. ${ }^{217}$ Mississippi was actually the first state to broadly permit pharmacists to deny the provision of contraceptives, ${ }^{218}$ and more recently, Missouri attempted to pass a bill that would have permitted employers and insurance providers to deny coverage for contraceptives. ${ }^{219}$

There are clearly those who find certain forms of contraception problematic, and conscience legislation serves to protect that individual (or institutional) belief. But properly understood, the adoption of a personhood framework could be viewed to represent a state-wide (at least majoritarian) acceptance of the principles upon which these birth control methods are condemned. ${ }^{220}$ Given the stated goal of the Personhood Movement to recognize and protect pre-embryonic human life, ${ }^{221}$ even if the measure itself did not immediately outlaw certain forms of birth control, if proponents seek to remain consistent with the position, it is entirely possible that they would push for their given state to regulate contraception more heavily in an effort to offer protection to these newly recognized persons.

There are personhood advocates who support an outright ban on certain forms of contraception as a means to protect pre-embryonic persons from those contraceptives that could potentially cause their death. ${ }^{222}$ But even if we take the

${ }^{213}$ Sepper, supra note 206, at 386 (discussing the Respect for Rights of Conscience Act, S. 1467, 112th Cong., (2011-2012), a law "that would have permitted any person or entity to refuse to provide any care even if the refusal results in a person's death").

${ }^{214}$ Pope, supra note 192, at 165.

${ }^{215} \mathrm{Id}$. at 164 .

${ }^{216} I d$. at 166

${ }^{217}$ See Will, Conscience Legislation, supra note 207, at 416 (citing STATE POLICIES IN BRIEF: Refusing to Provide Health Services, Guttmacher INST. (Sept. 2013), available at http://www.guttmacher.org/statecenter/spibs/spib_RPHS.pdf (identifying the six states as Arizona, Arkansas, Georgia, Idaho, Mississippi, and South Dakota)).

${ }^{218}$ Brittany L. Grimes, The Plan B for Plan B: The New Dual Over-the-Counter and Prescription Status of Plan B and Its Impact Upon Pharmacists, Consumers, and Conscience Clauses, 41 GA. L. REV. 1395, 1402 (2007) (citing Mary K. Collins, Conscience Clauses and Oral Contraceptives: Conscientious Objection or Calculated Obstruction?, 15 AnNals Health L. 37, 49 (2006)). In fact, the Mississippi statute permits conscientious objection by any person "who furnishes, or assists in the furnishing of" healthcare services, which is a term broadly defined to include "patient referral, counseling, therapy, testing, diagnosis or prognosis, research, instruction, prescribing, dispensing or administering any device, drug, or medication, surgery, or any other care or treatment." See Miss. CODE ANN. § 41-107-3, § 41-107-5 (West 2009).

${ }^{219}$ See Kevin Murphy, Missouri Law to Deny Birth Control Coverage Vetoed, ReUTERs (Jul. 12, 2012), http://www.reuters.com/article/2012/07/12/us-usa-contraception-missouriidUSBRE86B1B620120712.

${ }^{220}$ Will, Conscience Legislation, supra note 207, at 412 (highlighting Professor Sepper's suggestion that "a possible purpose behind conscience legislation is to 'make abortions, family planning, and end-of-life care more difficult to obtain,' and that the true goal of such legislation is 'hostility to reproductive health and patients' interests."' Sepper, supra note 206, at 406).

${ }^{221}$ See About Personhood, supra note 31.

${ }^{222}$ In a subsequent paper, I will discuss the constitutionality of any proposed restriction on hormonal contraceptives, but briefly, while Supreme Court precedent establishes that a state could not 
position that these forms of contraception carry the risk of causing death to a person, it does not necessarily follow that these forms of birth control must be banned. After all, the Constitution is currently interpreted to permit capital punishment, so it cannot be said that human life must always be protected. ${ }^{223}$ Perhaps to account for this, the revised personhood language only purports to protect "innocent" persons. ${ }^{224}$ Even still, there are many activities that are perfectly permissible notwithstanding the fact that they involve a significant risk of loss of innocent human life. ${ }^{225}$

For instance, in 2012 the United States Census Bureau reported statistics showing that nearly 34,000 people died in 2009 from motor vehicle accidents. ${ }^{226}$ While adults can surely make an autonomous decision to assume this risk, the many children under the age of fifteen who died in accidents ${ }^{227}$ did not make that choice. Because we permit adults to subject children to this known risk of loss of innocent human life, risk of loss of life alone does not seem sufficient to support an outright ban on an activity. By analogy, a parent driving her child hopes to arrive at her destination without having a car accident, though she is certainly aware of the risk that an accident will occur and that her child might die. Similarly, a woman using hormonal contraception may hope to avoid pregnancy without fertilization taking place, though she remains aware of the risk that pregnancy is avoided only after a person comes into existence and then dies when implantation fails or is disrupted. In either case, at the time the decision is made (to drive or use hormonal contraception), the woman does not know whether a death will result, and indeed, it would be very difficult to predict the likelihood that a death would result.

As a society, a decision has been made that it is acceptable for a certain number of lives to be lost (innocent or otherwise) in exchange for the convenience of motor vehicle transportation. Of course, the states regulate such transportation to make it as safe as possible. Few would question the convenience that comes with the ability to use contraception - the question would be, at what cost? Rather than immediately imposing an outright ban on forms of contraception that create a risk of loss of preembryonic life, we ought to ask what level of risk is acceptable, and what level of regulation is necessary to achieve it. The Guttmacher Institute recently reported that when used properly, the pill prevents pregnancy over ninety-nine percent of the time; however, it is not clear what proportion of that ninety-nine percent involved the death of a pre-embryonic person. ${ }^{228}$ This information would be relevant to properly make the assessment suggested here. ${ }^{229}$ Regardless of the result of such an

outlaw all forms of contraception, it is far less clear whether certain forms of contraception could be restricted given a state's (compelling?) interest in protecting pre-embryonic persons following adoption of a personhood framework. Cohen, supra note 15, at 1167-72; Mark Strasser, The Next Battleground? Personhood, Privacy, and Assisted Reproductive Technologies, 65 OKLA. L. REV. 177, 198-99 (2013); Will, Measure 26, supra note 81, at 74.

${ }^{223}$ See, e.g., Washington v. Glucksberg, 521 U.S. 702, 741 (1997) (Stevens, J., concurring).

${ }^{224}$ See infra Appendix I.

${ }^{225}$ See, e.g., Dylan P. Kletter, Negligence in the (Thin) Air: Understanding the Legal Relationship Between Outfitters and Participants in High Risk Expeditions Through Analysis of the 1996 Mount Everest Tragedy, 40 CoNN. L. REV. 769, 784 (2008) (noting that a mountain climber may choose to participate in a particular climb because of the likelihood of death).

${ }^{226}$ U.S. Census Bureau, fatal Motor Vehicle Accidents-National Summary: 19902009, at 694 tbl.1105 (2012), available at http://www.census.gov/compendia/statab/2012/tables/12s1105.pdf.

${ }^{227}$ The census data included a finding that 6.88 minors under the age of 15 died in vehicular accidents per 100,000 residents. Id.

${ }^{228}$ See GUTTMACHER, supra note 193

${ }^{229}$ One could also argue that the high rate of natural miscarriage (leading to the death of preembryonic persons) should lead to restrictions on unprotected sex itself. But personhood proponents 
inquiry, it cannot be said to be fear mongering to discuss the potential impacts of pre-embryonic personhood on contraception, and the types of restrictions ${ }^{230}$ that might follow if such a framework is adopted.

\section{B. PERSONHOOD AND IN VITRO FERTILIZATION}

Like contraception, debates surrounding Measure 26 in Mississippi revealed questions about whether passage of the amendment would outlaw IVF. As noted, the revised personhood language states that "only in vitro fertilization and assisted reproduction that kills a person" are affected. ${ }^{231}$ But if proponents are serious about extending the rights of legal personhood to pre-embryos, then protecting these persons from serious injury should also be a priority. Given the inherent risks to preembryos associated with IVF, there should be real concern that significant restrictions would result from the passage of a personhood measure either from the amendment itself or from subsequent legislation. ${ }^{232}$ Keith Mason has suggested that while personhood may not necessarily "ban" IVF, he would like to see it "reformed." 233 The question is how.

If a personhood framework is established utilizing the revised language, it is not clear what aspects of IVF would be immediately problematic, or might be subject to future restriction. In one of the few cases to consider the status of pre-embryos created in the IVF process, the court in Davis v. Davis suggested that if pre-embryos were afforded "the legal status of 'persons' . . . vested . . . with legally cognizable interests separate from those of their progenitors, [s] uch a decision would doubtless have had the effect of outlawing IVF programs in the [S] tate of Tennessee., ${ }^{234}$ Of particular importance here, the Davis Court explored Tennessee's public policies regarding the treatment of pre-embryos (as gleaned from the legal treatment of fetuses), and determined that pre-embryos "[could] not be considered 'persons' under Tennessee law."235 Affording this consideration to pre-embryos is, of course, the very purpose of the Personhood Movement.

For the same reasons mentioned in the context of contraception, I am not convinced that adoption of a personhood framework would require IVF to be expressly outlawed. Nevertheless, several of the procedures that are available within the process, such as pre-embryo selection, cryopreservation, pre-implantation genetic screening (PGS), and even the transfer process itself, pose significant risk of injury or destruction to the pre-embryos involved. ${ }^{236}$ The following section will

do not appear to be arguing for such restrictions, and the idea of the government regulating sexual activity itself (as opposed to the types of contraception or ART available) raises a host of constitutional problems that are beyond the scope of this project. See Lawrence v. Texas, 539 U.S 558,558 (2003) (finding a Texas statute that criminalized certain sexual behavior between members of the same sex to violate the Due Process Clause); see infra notes 339-52 and accompanying text for discussion of this issue in the context of IVF.

${ }^{230}$ In Germany and Italy, for instance, regulations limit the number of pre-embryos that may be created and transferred for implantation to reduce the risk of loss in the IVF process. See infra notes 273-274 and accompanying text.

${ }^{231}$ See infra Appendix I.

${ }^{232}$ Even if the amendment itself does not implicate injury caused to pre-embryos, it is possible that other statutory provisions would be available to address such harms. See supra notes 151-57 and accompanying text (discussing unintentional drug-induced miscarriages).

${ }^{233}$ Kounang, supra note 17; Pesta, supra note 41.

${ }^{234}$ Davis v. Davis, 842 S.W.2d 588, 595 (Tenn. 1992).

${ }^{235} \mathrm{Id}$. at $594-95$.

${ }^{236}$ See Bridget M. Fuselier, The Trouble With Putting All of Your Eggs in One Basket: Using a Property Rights Model to Resolve Disputes Over Cryopreserved Pre-Embryos, 14 TEX. J. C.L. \& C.R. 
discuss the risks associated with these procedures, and the types of restrictions on the practice of IVF that might be expected under a personhood framework. ${ }^{237}$ Even without an outright ban on IVF, such restrictions could be stringent enough to make it effectively impossible for these reproductive services to be provided.

\section{Pre-Embryo Creation, Selection, and Cryopreservation}

In order for pre-embryos to be created, the male and female gametes (sperm and ova) must be retrieved. ${ }^{238}$ The process for obtaining ova (or oocytes) is significantly more "onerous, painful, and risky than acquiring sperm," 239 and it is also very expensive. ${ }^{240}$ The woman from whom ova will be retrieved must undergo daily injections of hormones to stimulate her ovaries to produce mature oocytes, which are then extracted laparoscopically using a needle guided by ultrasound. ${ }^{241}$ Clinicians attempt to retrieve as many ova as possible, not just because of the cost and burden of the retrieval process, but also to increase the chances of successful fertilization and development. ${ }^{242}$ In addition, clinicians will typically attempt to fertilize each of the ova retrieved, due to the low success rate historically associated with the cryopreservation of unfertilized ova. ${ }^{243}$

During the first forty hours following introduction of the sperm to the ovum, an inspection is performed to determine whether cellular division has commenced. ${ }^{244}$ Clinicians visually inspect the form and structure (morphology) of the pre-embryos in order to select those of the highest quality ${ }^{245}$ for immediate use in implantation. ${ }^{246}$ The "least robust" pre-embryos identified through this visual inspection are typically discarded, and sufficiently robust, though perhaps not the best pre-embryos that exceed the number to be immediately implanted are commonly cryopreserved. ${ }^{247}$

143, 146 (2009); Jaime King, Predicting Probability: Regulating the Future of Preimplantation Genetic Screening, 8 YAle J. HeAlth POL’y L. \& ETHICS 283, 292-93 n.37 (2008).

${ }^{237}$ In a subsequent paper, I will explore the constitutionality of any such restrictions. See supra note 23 .

${ }^{238}$ Fuselier, supra note 236, at 146

${ }^{239}$ Id

${ }^{240}$ Many fertility clinics do not itemize the various costs associated with an IVF cycle on their websites, but at least two clinics advertised egg retrieval costs that alone exceed $\$ 2,000$. Sample IVF Costs, ReProD. HEALTH CTR. (2012), http://www.ivftucson.com/financial-information/sample-ivfcosts; Fertility, QUILLEN ETSU PHYSICIANS (2012), http://www.etsuphysicians.com/medicalservices/fertility.html (select "What are my costs?" from the left-hand panel).

${ }^{241}$ Fuselier, supra note 236, at 146-47.

${ }^{242} \mathrm{Id}$. at 146 n.20.

${ }^{243} I d$. at 147 . As will be discussed, research involving the cryopreservation of ova (as opposed to pre-embryos) is ongoing, and may offer an alternative that would seem more permissible under a personhood framework.

${ }^{244} I d$. at 144.

${ }^{245}$ See, e.g., Meredith A. Reynolds et al., Risk of Multiple Birth Associated with In Vitro Fertilization Using Donor Eggs, 154 AM. J. EPIDEMIOlogy 1043, 1044 (2001). This visual inspection is to be distinguished from the genetic testing associated with PGS.

246 Maureen Wood, Embryo Freezing: Is it Safe?, IVF.NET (Aug. 2, 2004), http://www.ivf.net/ivf/embryo-freezing-is-it-safe-0335.html (noting that the "best" pre-embryos are selected for fresh IVF cycles, as opposed to cryopreserving the best pre-embryos). Even where successful pregnancy and birth is achieved through IVF, because of a lack of studies (and the fact that symptoms may not appear for years), it is not well understood whether potential genetic abnormalities or defects may be caused by the IVF process. See Gina Kolata, Picture Emerging on Genetic Risks of $\begin{array}{lllll}\text { IVF, N.Y. } & \text { TIMES, } & \text { Feb. } & 16, & \text { 2009, }\end{array}$ http://www.nytimes.com/2009/02/17/health/17ivf.html?_r=1\&nl=8hlth\&emc=hlthal. Further understanding of these issues could lead to restrictions on the practice of IVF without regard to personhood.

\footnotetext{
${ }^{247}$ Peters, supra note 174, at 217.
} 
Under a personhood framework the visual inspection and discarding of pre-embryos could be problematic, as could cryopreservation.

If personhood attaches within the first twenty-four hours after the sperm penetrates the egg, then a person would exist at the time the visual inspection is made. Proponents may seek to impose restrictions on the techniques and protocol used by clinicians to determine whether a given pre-embryonic person is fit for implantation. For instance, it is possible that cellular division fails to initiate or that otherwise very little development occurs after the sperm penetrates the egg. ${ }^{248}$ In this situation personhood proponents might agree that the pre-embryonic person is not alive (or no longer alive?), ${ }^{249}$ though they may still call for compassionate treatment ${ }^{250}$ of this deceased person.

On the other hand, cellular division may begin, but the morphology of the preembryo may suggest that development is abnormal and unlikely to result in successful implantation or pregnancy. Given the stated goal of protecting all life, without exception, ${ }^{251}$ proponents would likely be uncomfortable with clinicians discarding living, though abnormal, pre-embryonic persons based on visual inspection. Under a personhood framework, it could be mandated that these preembryos either be transferred into the woman (and thus, at least given a chance at continued development, ${ }^{252}$ as opposed to the certain death that discarding would bring), or that they be cryopreserved. ${ }^{253}$ While cryopreservation offers many benefits, it also presents its own problems. ${ }^{254}$

Cryopreservation is a routine part of the IVF process, ${ }^{255}$ and it typically takes place when the pre-embryo is in the four- to eight-cell stage. ${ }^{256}$ The existence of cryopreservation as an available option reduces the number of egg extractions a woman must undergo, and allows clinicians to transfer a smaller number of pre-

\footnotetext{
${ }^{248}$ See Fuselier, supra note 236, at 144.

${ }^{249}$ The awkwardness of using the language of "life" and "person" in this context highlights the deficiencies associated with ignoring the biological realities of the early reproductive process previously discussed. Under Louisiana law pre-embryos are recognized as juridical persons; however, if the fertilized ovum fails to develop (other than due to cryopreservation), it is considered nonviable, and not a juridical person. LA REV. STAT. ANN. § 9:129 (2008). Similarly, a statute was recently proposed in Georgia that would have identified pre-embryos as human beings, but also included the statement that a pre-embryo that "fails to show any sign of life over a 36 hour period outside a state of cryopreservation shall be considered no longer living." S.B. 169, 150th Gen. Assemb. Reg. Sess. (Ga. 2009), available at http://www.legis.ga.gov/Legislation/20092010/89683.pdf (emphasis added).

${ }^{250}$ Even a national infertility organization that opposes personhood initiatives advises those undergoing IVF to inquire as to the options available for any pre-embryos (unfit or otherwise) not transferred to the woman's uterus. One option listed is a "disposal ceremony," designed to create "a special moment to come to closure regarding the [pre-]embryos." After IVF: The Embryo Decision, RESOLVE: NAT'L INFERTILITY ASS'N (2013), http://www.resolve.org/family-building-options/donoroptions/after-ivf-the-embryo-decision.html.

${ }^{251}$ About Personhood, supra note 31.

${ }^{252}$ We might question whether attempted implantation would be appropriate in these circumstances. Under a personhood framework, this abnormal pre-embryo would possess the same legal and moral status as you or I do. If clinicians determine that this pre-embryo has a very low probability of surviving the implantation process, then what justification would there be for sending this person we are trying to protect off to near certain death? Would it not be better to cryopreserve the pre-embryo in the hopes that one day technology would improve the odds of successful implantation and pregnancy? See infra notes 339-52 and accompanying text for further discussion of the risks associated with the transfer process.

${ }^{253}$ See, e.g., Personhood Doesn't Ban IVF, a Response to Atlee Breland, Personhood USA (2013), http://www.personhoodusa.com/blog/personhood-doesnt-ban-ivf-response-atlee-breland/

${ }^{254}$ See, e.g., Fuselier, supra note 236, at 147.

${ }^{255}$ Wood, supra note 246.

${ }^{256}$ Peters, supra note 174 , at 217.
} 
embryos into a woman in a given cycle (thereby reducing the risk of multiple births), because excess pre-embryos can be saved for later use. ${ }^{257}$ But the cryopreservation process also presents risk of injury or destruction to the pre-embryonic persons involved, which stems from the freezing and thawing processes, as well as the state and duration of being frozen. ${ }^{258}$

In order to survive the freezing process, pre-embryos must "withstand potentially lethal ice formation, transmembrane water movement and extreme changes in external electrolyte concentrations, temperature and $\mathrm{pH} .{ }^{, 259}$ Then they must survive the reversal of these conditions associated with the thawing process. ${ }^{260}$ While it is theoretically possible to keep pre-embryos frozen indefinitely, it is unclear whether, after a certain period of time, the pre-embryos become unsuitable for implantation. ${ }^{261}$ In 2010 there was a successful birth resulting from the use of a pre-embryo that had been frozen for nearly twenty years; though it is worth noting that there were originally five such pre-embryos: only two survived the thawing process and were implanted, and only one resulted in a live birth. ${ }^{262}$ In other words, eighty percent of the pre-embryonic persons involved died in the process, which may not be considered a success story.

The survival rates for cryopreserved pre-embryos vary from clinic to clinic with anywhere from $20-40 \%$ not surviving the freezing and thawing process. ${ }^{263}$ In addition, at least some studies have shown that successful pregnancies are less likely to occur when using thawed as opposed to fresh pre-embryos, ${ }^{264}$ and unsuccessful implantation obviously leads to the death of the pre-embryonic person involved. Further, the risks associated with cryopreservation are not limited to survival of the pre-embryo or suitability for implantation. ${ }^{265} \mathrm{We}$ are only just beginning to study the question of whether freezing can cause genetic modification and/or defects, some of which may not be expressed until years after birth. ${ }^{266}$

This data would clearly be relevant in assessing whether cryopreservation poses an unacceptable risk of death or injury to pre-embryonic persons. In the meantime, knowledge of these risks could very realistically lead to restrictions on the use of cryopreservation under a personhood framework. After all, once we've identified a pre-embryonic person, decisions made (or regulations imposed) regarding that

${ }^{257}$ Fuselier, supra note 236, at 147.

${ }^{258} \mathrm{Id}$

${ }^{259}$ Wood, supra note 246

${ }^{260}$ Id.

${ }^{261}$ Whether cryopreserved persons are "alive" as opposed to being in some sort of limbo, or whether they are (or ought to be) entitled to the same legal rights and protections as "thawed" persons are also interesting questions.

${ }^{262}$ Cynthia S. Marietta, Birth of Healthy Baby from 20-Year-Old Frozen Embryo Raises Ethical Questions, UNIV. Hous. LAW CTR. 1, 1-2 (Jan. 2011), http://www.law.uh.edu/healthlaw/perspectives/2011/(CM)\%20IVF.pdf.

${ }^{263}$ Wood, supra note 246. See Marietta, supra note 262.

${ }^{264}$ Wood, supra note 246. The data reported by the CDC indicate that, as a percentage of transfers resulting in live birth, fresh transfers are more successful for women under the age forty, but less successful than thawed transfers for women forty-one and older. See Assisted Reproductive Technology (ART) Report, CTRS FOR DiseAse CONTROL \& Prevention (2010), http://apps.nccd.cdc.gov/art/Apps/NationalSummaryReport.aspx .

${ }^{265}$ See Marietta, supra note 262, at 3-4 (explaining that the combination of freezing/thawing techniques could potentially pose medical risks to resulting children).

${ }^{266}$ See, e.g., id. (describing recent work performed by the Jones Institute, a preeminent IVF research institute in Norfolk, Virginia, and generally noting the limited number of studies conducted regarding IVF-conceived children); see also Gina Kolata, Picture Emerging on Genetic Risks of IVF,

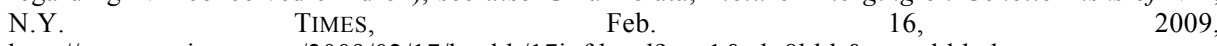
http://www.nytimes.com/2009/02/17/health/17ivf.html?_r=1\&nl=8hlth\&emc=hlthal. 
person-including whether it is permissible to subject the person to cryopreservation $^{267}$ — can fairly be scrutinized using a best interests standard. ${ }^{268}$ While this is certainly true with respect to activities potentially resulting in the death of these persons who would have a constitutionally protected right to life, it can be more complicated when discussing the permissibility of genetic interventions that might be said to harm the pre-embryonic persons involved. The best interests standard seems appropriate, assuming (rightly or wrongly), as I believe personhood proponents would, that any genetic intervention that impacts pre-embryonic persons, though does not bring about death, would be identity-preserving. ${ }^{269}$ In other words, that any genetic damage that might occur as a result of cryopreservation would not change the identity of the pre-embryonic person involved, and thus we can say that harm involved has occurred to a presently-existing (not future, as-yet unidentified) person. $^{270}$

As a result, it may be mandated that pre-embryos in a current state of cryopreservation remain frozen until the thawing technique becomes safer. Further, future cryopreservation of pre-embryonic persons could be outlawed entirely, with fertility clinics permitted to fertilize only those ova that will be immediately implanted. In Italy, cryopreservation of pre-embryos is expressly prohibited because "it constitutes an offence against the respect due to human beings . . .."271 Clinicians may fertilize no more than three ova in a given cycle, and each pre-embryo created must be transferred, regardless of its health status. ${ }^{272}$ While not expressly outlawing cryopreservation, Germany's Embryo Protection Act makes it a crime to attempt to fertilize more ova than may be transferred in one cycle, and permits no more than three pre-embryos to be transferred. ${ }^{273}$

${ }^{267}$ This argument is equally applicable to any harm that might occur as a result of PGS, which is discussed below.

${ }^{268}$ See Davis v. Davis, 842 S.W.2d 588, 594 (Tenn. 1992) (noting that after the trial judge determined that the pre-embryos should be treated as "children in vitro," the judge "then invoked the doctrine of parens patriae and held that it was 'in the best interest of the children' to be born rather than destroyed"); see also LA. REV. STAT. ANN. § 9:131 (2012) (stating that "in disputes arising between any parties regarding the in vitro fertilized ovum, the judicial standard for resolving such disputes is to be in the best interests of the in vitro fertilized ovum").

${ }^{269}$ See infra note 299.

${ }^{270}$ See generally I. Glenn Cohen, Regulating Reproduction: The Problem with Best Interests, 96 MinN. L. REV. 423 (2012); I. Glenn Cohen, Beyond Best Interests, 96 MinN. L. REV. 1187 (2012) (In a two-article series, Cohen arguing that the best interests standard, utilized to protect existing children, does not seem satisfying as a justification for restricting reproductive choices that might impact future children.). For instance, in arguing against potential restrictions on say the elderly having access to IVF, Professor Cohen uses Parfit's Non-Identity Problem to note that assuming the resulting child would have a life worth living, such child cannot be said to be harmed by permitting the elderly person to undergo IVF, since the alternative would be no life at all. See DEREK PARFIT, REASONS AND PERSONS 358-61 (1984). Assuming that the genetic interventions I discuss in this paper are identity-preserving, Professor Cohen's argument against the use of the best interests standard would not be implicated, since the pre-embryonic persons involved are already in existence and thus, we are not speaking about harming future persons. See infra note 299 for additional discussion of this issue.

${ }^{271}$ Jeffrey T. Wise, Comment, Embryo Banking as a Novel Option for the Infertile? Law, Policy, and a Proposed Model Act, 8 Hous. J. HeAlth L. \& PoL'Y 163, 181 (2007) (citing Rachel Anne Fenton, Catholic Doctrine Versus Women's Rights: The New Italian Law on Assisted Reproduction, 14 MED. L. REV. 73, 98 (2006)).

${ }^{272}$ Id.

${ }^{273}$ Gesetz zum Schutz von Embryonen [ESchG][The Embryo Protection Act], Dec. 13, 1990, BUNDESRAT DRUCKSACHEN [BR], 69/90 at 2746 (Ger.), translation available at http://www.auswaertiges-

amt.de/cae/servlet/contentblob/480804/publicationFile/5162/EmbryoProtectionAct.pdf. 
Recent personhood efforts in the State of Georgia at the legislative level are also informative. ${ }^{274}$ In 2009 the organization Georgia Right to Life helped to draft a bill that would have offered legal protection ${ }^{275}$ to pre-embryos as "biological human being[s] who [are] not the property of any person or entity." ${ }^{276}$ As introduced to the Senate, the bill would have effectively outlawed the future use of cryopreservation by prohibiting clinics from creating more pre-embryos in a single cycle than would be transferred in that cycle. ${ }^{277}$ The initial draft also limited the number of acceptable transfers in a given cycle to two pre-embryos for women under forty, and three preembryos for women over forty. ${ }^{278}$ Opponents successfully lobbied against these provisions by arguing that they would impede infertility treatments. ${ }^{279}$ Indeed, since passage of Italy's very restrictive regulations on IVF, the rate of Italians seeking fertility treatments in other countries (fertility tourism) has tripled. ${ }^{280}$ Nonetheless, the original language proposed in Georgia ${ }^{281}$ highlights the type of restrictions we might expect if a personhood measure passes in the future.

One possible result of such restrictions would be the devotion of further research to improving techniques for freezing and thawing ova which, while currently considered experimental, ${ }^{282}$ would not involve a risk to human life under a personhood framework. Although freezing and thawing eggs has historically been

${ }^{274}$ See, e.g., Georgia's "Personhood Amendment” Passes with a Super Majority, GA. RigHT TO LiFE (Aug. 2, 2012), http://www.grtl.org/?q=node/270; see also Jim Galloway, A House Democrat to Sponsor Personhood Amendment, AtLanta Journal-Constitution (Nov. 15, 2011), http://blogs.ajc.com/political-insider-jim-galloway/2011/11/15/a-house-democrat-to-sponsorpersonhood-amendment/.

${ }^{275}$ Betsy McKay, In-Vitro Fertilization Limit is Sought, WALl ST. J., Mar. 3, 2009, http://online.wsj.com/article/SB123603828823714509.html.

276 S.B. 169, 150th Gen. Assemb. Reg. Sess. § 19-7-64(a) (Ga. 2009), available at http://www.legis.ga.gov/Legislation/20092010/89683.pdf.

${ }^{277} I d$. at $\S 19-7-66$. A more recent bill that was proposed to accompany a personhood amendment in North Dakota was struck down by the State Senate that would have similarly restricted the number of embryos created to those that would be transferred in a given cycle. S.B. 2302, 63d Legis. Assemb., $\$ 7$ (N.D. 2013), available at http://www.legis.nd.gov/assembly/63-2013/documents/13-823102000.pdf?20130213153739

278 S.B. 169, 150th Gen. Assemb. Reg. Sess. \& 19-7-67 (Ga. 2009), available at http://www.legis.ga.gov/Legislation/20092010/89683.pdf. At least with respect to the number of transfers permitted, the legislation is not dramatically different than the recommendations and guidelines established by the American Society of Reproductive Medicine, or current practices within IVF clinics in the United States. See infra notes 328-33 and accompanying text. This suggests an area where those in favor of IVF may find common ground with personhood proponents.

${ }^{279}$ See, e.g., The National Infertility Association and Supporters Defeat Dangerous Georgia Bill, RESOLVE: NAT'L INFERTILITY Ass'N (Apr. 9, 2009), http://www.resolve.org/about/resolve-thenational-infertility-association-and-supporters-defeat-dangerous-georgia-bill.html (recounting how "the outrage from the family building community forced Georgia legislators to backpedal, re-write, and delete many of the provisions of the bill that would have harmed infertility patients").

${ }^{280}$ Wise, supra note 271 , at 181 .

${ }^{281}$ The version of S.B. 169 that passed in the Senate does not contain the language regarding cryopreservation or limited pre-embryo transfer. See S.B. 169, 150th Gen. Assemb. Reg. Sess. § 19-7 (Ga. 2009), available at http://legiscan.com/GA/text/SB169/2009 (permitting pre-embryo cryopreservation, though limiting the ways in which pre-embryos may be created, and providing that pre-embryos may be created "solely for the purposes of initiating a human pregnancy").

${ }^{282}$ Lisa Campo-Engelstein, Insurance Coverage for Cancer Treatment-Induced Conditions. Comparing Fertility Preservation Technology and Breast Reconstructive Surgery, 61 DEPAUL L. REV 849, 856 (2012) (noting that the American Society for Reproductive Medicine (ASRM) still considers egg cryopreservation to be experimental); see also U.B. Wennerhold et al., Children Born After Cryopreservation of Embryos or Oocytes: A Systematic Review of Outcome Data, 24 HumAn ReProD. 2158, 2169 (2009), available at http://humrep.oxfordjournals.org/content/24/9/2158.full.pdf $+\mathrm{html}$ (stating that data on children born after egg cryopreservation is "sparse"). 
less successful than freezing and thawing pre-embryos ${ }^{283}$ recent reports suggest that methods are improving. ${ }^{284}$ Success in this endeavor would also address the issue of women having to undergo multiple egg-extraction procedures where pre-embryo cryopreservation is prohibited.

\section{Preimplantation Genetic Screening ${ }^{285}$}

Regardless of whether fresh or thawed pre-embryos are to be transferred, the participants in IVF increasingly choose to have PGS performed. ${ }^{286}$ PGS requires the removal of one of the cells from a four- to eight-cell pre-embryo and testing it for certain genetic characteristics. ${ }^{287}$ At the point when PGS is performed, each cell within the pre-embryo contains a fully-assembled, though inactive genome, and each cell is totipotent, with the capability of developing into a separate human being. ${ }^{288}$ Because the extracted cell is destroyed in the testing process, if the cell itself is considered a separate person that would obviously seem problematic. ${ }^{289}$

That said, PGS can be used to identify genetic abnormalities that would not have been caught through the visual inspection of the pre-embryos. ${ }^{290}$ The most severe abnormalities are fatal, but under current practice, if PGS reveals any unwanted genetic characteristic (for instance, trisomy 21 - Down syndrome) the preembryos would typically just be discarded or donated for research. ${ }^{291}$ Clinics have also permitted the use of PGS for purposes of selecting pre-embryos for implantation that have certain desired traits such as a particular gender or those likely to develop into children with deafness or dwarfism. ${ }^{292}$ And again, if infertility treatment ends before the supply of pre-embryos is exhausted, the unused pre-embryos (including those without the desired gender or those likely to develop into hearing children or children of normal height) are typically discarded or donated for research. ${ }^{293}$ Discarding or donating pre-embryos for research would be problematic under a personhood framework that strives to protect human life regardless of disability or the existence of particular genetic traits.

\footnotetext{
${ }^{283}$ Fuselier, supra note 236, at 147.

${ }^{284}$ Charles P. Kindregan, Jr., Genetically Related Children: Harvesting of Gametes from Deceased or Incompetent Persons, J. Health \& Biomed. L. 147, 158 n.50 (2011) (citing Briana Rudick et al., The Status of Oocyte Cryopreservation in the United States, 94 FERTILITY \& STERILITY 2642, 2642-46 (2010)).

${ }^{285}$ PGS is used here to refer to any genetic testing of pre-embryos, though some commentators distinguish between PGS and preimplantation genetic diagnosis (PGD). See, e.g., Jaime King, Duty to the Unborn: A Response to Smolensky, 60 HASTINGS L.J. 377, 379 n.15 (2008) (using the term PGD with reference to testing for specific genetic or chromosomal diseases).

${ }^{286}$ The use of PGS has grown significantly since its introduction in the late 1980s. King, supra note 285 , at 290 n.28.

${ }^{287}$ Peters, supra note 174 , at 216

${ }^{288} \mathrm{Id}$. at $210-16$

${ }^{289}$ For instance, Germany's Embryo Protection Act includes in its definition of "embryo" "each totipotent cell removed from an embryo that is assumed to be able to divide and to develop into an individual under the appropriate conditions." Gesetz zum Schutz von Embryonen [ESchG][The Embryo Protection Act], Dec. 13, 1990, BundeSRAt DRUCKSACHen [BR], 69/90 at 2746 (Ger.), translation available at $\mathrm{http} / / / \mathrm{www}$.auswaertigesamt.de/cae/servlet/contentblob/480804/publicationFile/5162/EmbryoProtectionAct.pdf.

${ }^{290}$ King, supra note 285, at 292.

${ }^{291}$ Id. at 291. In addition to identifying chromosomal abnormalities, PGS can be used to screen for genetic markers associated with disorders such as Tay-Sachs and Huntington's, or for predispositions to certain cancers. Id. at 296.

${ }^{292} I d$. at 295-96.

${ }^{293}$ Peters, supra note 174, at 217.
} 
Beyond this, the cell biopsy used to extract the cell to test for genetic characteristics creates the risk of causing damage to the pre-embryo that could render it unfit for implantation or otherwise lead to birth defects. ${ }^{294}$ As Professor King has noted, the nature and extent of these risks are not well understood. ${ }^{295}$ Logic might suggest that pre-embryos lacking genetic abnormalities have a higher probability of leading to successful pregnancy in a given IVF cycle, but certain studies have shown that pre-embryos implanted after PGS are less likely to result in pregnancy and birth. ${ }^{296}$ More research is needed to determine whether the process of PGS itself is to blame for this increased IVF mortality rate for pre-embryonic persons. ${ }^{297}$ Further, even if implantation and birth are successful, there is the possibility that removing a cell from the pre-embryo could cause developmental and other health problems later in life. ${ }^{298}$ Knowingly exposing pre-embryonic persons to these as-yet unquantifiable risks of death or injury could be viewed as problematic under a personhood framework.

A significant problem with PGS has to do with the lack of benefit that such testing provides to the pre-embryonic person involved (notwithstanding the clear benefit to the prospective parents seeking the testing), especially when considering the risks inherent in the procedure. ${ }^{299} \mathrm{We}$ currently lack the technology to perform genetic modification or alteration to correct any genetic abnormality that might be discovered using PGS. ${ }^{300}$ If the IVF patients planned to transfer the pre-embryos regardless of the PGS results, then perhaps the pre-embryo would benefit in the future to the extent the patients used this information to plan for raising a child with the identified condition. But this attenuated benefit would not seem to justify exposing the pre-embryos to the risks of death or injury identified here.

Beyond this type of utilitarian assessment, the President's Council on Bioethics noted that, particularly in the context of using PGS to identify a donor match for an

\footnotetext{
${ }^{294}$ King, supra note 285, at 287.

${ }^{295} \mathrm{Id}$. at $291-96,303-08$.

${ }^{296} \mathrm{Id}$. at $292 \mathrm{n} .37,297$. The study indicated a $37 \%$ live birth rate for IVF patients, decreasing to $25 \%$ for patients undergoing PGS. Id. at 287 n.16, 307.

${ }^{297} I d$. at 308 .

${ }^{298} \mathrm{Id}$. at 307 (noting that the extent of this risk is unknown since many of the children born after a PGS cycle are not yet through puberty).

${ }^{299}$ For purposes of this paper I will bracket off the issue that some couples may only reproduce because of the availability of PGS, and therefore, PGS could be argued to provide the benefit of existence itself. This argument could be used by a patient only willing to parent a deaf child, which PGS makes possible through pre-embryo selection. In addition to the benefit, Parfit's Non-Identity Problem could be utilized to suggest that the decision to use PGS cannot be said to harm these resulting persons who are better off alive than not (at least assuming a life worth living). See PARFIT, supra note 270, at 358-61. But if the decision to use PGS is made after the pre-embryonic person is already in existence (for instance by a couple in the midst of using IVF), then the Non-Identity Problem would not appear to be implicated assuming we consider the genetic intervention to be identity preserving, and it is therefore possible to assess whether PGS causes or creates a risk of harm to this identified person. See I. Glenn Cohen, Intentional Diminishment, the Non-Identity Problem, and Legal Liability, 60 Hastings L.J. 347, 352-53 (2008); Kirsten Rabe Smolensky, Creating Children with Disabilities: Parental Tort Liability for Preimplantation Genetic Interventions, 60 HASTINGS L.J. 299, 332-33 (2008). Of course, if the genetic intervention is viewed to be identity changing, then the argument could be made that this "new," post-intervention person has not been harmed, since but for the intervention she would not exist. See supra notes 268-71 and accompanying text for additional discussion of this issue.

${ }^{300}$ See John A. Robertson, Extending Preimplantation Genetic Diagnosis: The Ethical Debate, 18 Hum. REPROD. 465, 470 (2003), available at http://humrep.oxfordjournals.org/content/18/3/465.full.pdf (explaining that controversial uses of preimplantation genetic diagnosis would increase if technology for further genetic testing was available).
} 
already born sibling, PGS could also raise a Kantian ${ }^{301}$ concern that such testing treats pre-embryonic persons as "a means for the benefit of another.",302 These issues become more apparent when considering that in the absence of PGS, all pre-embryos that pass visual inspection would likely be implanted or at least temporarily cryopreserved. ${ }^{303}$

Leaving aside the eugenic implications of using PGS to select offspring with desired traits, ${ }^{304}$ under a personhood framework, PGS would appear to be particularly susceptible to outlaw or severe restriction due to the risks involved and the questionable benefits to the pre-embryonic persons on whom testing is performed. ${ }^{305}$ Although currently unregulated in the United States, ${ }^{306}$ other countries offer examples of what such restrictions on PGS might look like. ${ }^{307}$

Italy, Austria, and Switzerland have statutes that ban the practice of PGS altogether. ${ }^{308}$ In addition, the Embryo Protection Act in Germany was historically interpreted to provide a blanket prohibition on $\mathrm{PGS},{ }^{309}$ but a recent court decision ${ }^{310}$ led to subsequent legislation that now permits PGS in the narrow circumstances where the parents have a high risk of passing on a serious genetic disease, or where the pre-embryo is suspected of carrying a defect that creates a high feasibility of miscarriage or stillbirth. ${ }^{311}$ At the time, three bills were considered in Germany, one of which would have explicitly prohibited all PGS. ${ }^{312}$ Those disfavoring any

${ }^{301}$ Utilitarianism and Kantianism are two moral theories that have had profound influence on Western legal philosophy. See, e.g., Jeffrie G. Murphy \& Jules L. Coleman, Philosophy of LaW 67-98 (1990). Kant himself might dispute the personhood (or humanity) of pre-embryos given their inability to engage in rational behavior. $I d$. at 77 .

302 President's Council on Bioethics, The Regulation of New Biotechnologies 96 (2004), http://bioethics.georgetown.edu/pcbe/reports/reproductionandresponsibility/_pcbe_final_repr oduction_and_responsibility.pdf.

${ }^{303}$ By avoiding immediate destruction these pre-embryos would stand the chance of being saved by a subsequent personhood framework that would outlaw destruction.

${ }^{304}$ See generally Michael J. Malinowski, Choosing the Genetic Makeup of Children: Our Eugenic Past-Present, and Future?, 36 CONN. L. REV. 125 (2003) (exploring the history of eugenics and how that history should inform regulation of ART).

${ }^{305}$ See generally Glenn L. Schattman, Lack of Benefit of Pre-Implantation Genetic Screening, 1 BIENNIAL REV. INFERTILITY 289 (2009) (explaining that PGS may reduce a woman's chance of having a child).

${ }^{306}$ See Benjamin B. Williams, Note, Screening for Children: Choice and Change in the "Wild West” of Reproductive Medicine, 79 GEO. WASH. L. REV. 1305, 1306-07 n.10 (2011).

${ }^{307}$ King, supra note 285 , at 136-37.

${ }^{308} I d$. at 137. Italy's outright ban of PGS was condemned recently by the European Court of Human Rights in a case involving an Italian couple (both carriers of cystic fibrosis) prevented from utilizing PGS. Europe Rights Court Condemns Italy Ban on Embryo Testing, RAW STORY (Aug. 28, 2012), http://www.rawstory.com/rs/2012/08/28/europe-rights-court-condemns-italy-ban-on-embryotesting/ (noting that "of 32 Council of Europe member states examined, only Italy, Austria and Switzerland ban PGD testing").

${ }^{309}$ King, supra note 285, at 137-38. (citing Gesetz zum Schutz von Embryonen [ESchG][The Embryo Protection Act], Dec. 13, 1990, BundesRat DRUCKSACHEN [BR], 69/90 at 2746 (Ger.), translation available at $\quad \mathrm{http} / / \mathrm{www}$.auswaertigesamt.de/cae/servlet/contentblob/480804/publicationFile/5162/EmbryoProtectionAct.pdf).

${ }^{310}$ German Government Divided over Calls for Embryo Protection, SPIEGEL ONLINE (Jul. 12, 2010), http://www.spiegel.de/international/germany/bio-ethical-battleground-german-governmentdivided-over-calls-for-embryo-protection-a-706040.html.

311 Gesetz zur Regelung der Präimplantationsdiagnostik, Sept. 2, 2011, BundeSRAT $\begin{array}{llllll}\text { DRUCKSACHEN } & {[\mathrm{BR}]} & 480 / 11 & \text { (2011) (Ger.), }\end{array}$ http://www.bundesrat.de/cln 171/SharedDocs/Drucksachen/2011/0401-500/480-

11 ,templateId=raw, property $=$ publicationFile.pdf/480-11.pdf (unofficial translation provided by Professor Christoph Henkel, Mississippi College School of Law).

${ }^{312}$ Philippa Brice, Germany Debates Preimplantation Genetic Diagnosis, PHG Foundation (Apr. 29, 2011), http://www.phgfoundation.org/news/8326/. 
exceptions that would allow PGS argued that it is "unacceptable that [pre-]embryos could be destroyed through [PGS] procedures," and that there should "be no selection between handicapped and non-handicapped life." ${ }^{313}$ It is likely that the same arguments would be made in support of an absolute prohibition on PGS under a personhood framework, though certainly other countries regulate PGS without banning the procedure entirely. ${ }^{314}$

\section{Transfer, Selective Reduction, and Disposition of Unused Pre-Embryos}

After pre-embryos are successfully created, screened, and potentially frozen and thawed, decisions remain regarding how many to transfer to the woman, what to do in the event of multiple implantations, and what to do with any pre-embryos that remain unused. In reverse order, it would be problematic under a personhood framework to discard unused pre-embryos or to donate them for research. This is certainly true in Italy where all created pre-embryos must be implanted, ${ }^{315}$ and it is also the case in Germany where "[a]nyone who disposes of" a pre-embryo or "uses it for a purpose not serving its preservation" will be imprisoned for up to three years. ${ }^{316}$ In the United States, Louisiana already makes it is illegal to intentionally destroy viable pre-embryos, ${ }^{317}$ and any unused pre-embryos must be made available for adoption by other IVF patients. ${ }^{318}$ Not surprisingly, the initial draft of the proposed personhood legislation in Georgia also specifically prohibited the intentional destruction of pre-embryos for any purpose ${ }^{319}$ and, as mentioned, even the revised Georgia language states that pre-embryos may be created "solely for the purposes of initiating a human pregnancy." 320

Continuing in reverse order, it is also readily apparent that selective reductions - termination of certain fetuses when multiple implantations occur ${ }^{321}$ would be frowned upon by personhood proponents. This technique may be utilized to make it safer for the woman and the remaining fetuses, or simply when the intended parents do not desire to have multiple children, whether the pregnancy is

\footnotetext{
${ }^{313}$ Government Divided, supra note 310.

${ }^{314}$ See generally King, supra note 285 (exploring regulatory models from other countries and offering a proposal for regulation of PGS in the United States). Professor King notes that in the Netherlands PGS can only be used to identify "serious conditions," with a goal of bringing about the birth of a healthy child. Id. at 166 . Personhood proponents would likely be unwilling to entertain a discussion about whether certain conditions are serious enough to permit the destruction of a human person, and even if the probability of miscarriage or stillbirth was $100 \%$, proponents may not feel that PGS is justified.

${ }^{315}$ See supra notes 271-72 and accompanying text.

${ }^{316}$ Gesetz zum Schutz von Embryonen [ESchG] [The Embryo Protection Act], Dec. 13, 1990, BUNDESRAT DRUCKSACHEN [BR], 69/90 at 2746 \& 2.1 (Ger.), translation available at http://www.auswaertiges-

amt.de/cae/servlet/contentblob/480804/publicationFile/5162/EmbryoProtectionAct.pdf.

${ }^{317}$ LA. REV. STAT. ANN. § 9:129 (2008).

${ }^{318} I d . \S 9: 130$.

319 S.B. 169, 150th Gen. Assemb. Reg. Sess. § 19-7-63(a) (Ga. 2009), available at http://www.legis.ga.gov/Legislation/20092010/89683.pdf

${ }^{320}$ See supra note 281.

${ }^{321}$ See ASRM, Criteria for Number of Embryos to Transfer: A Committee Opinion, 99 FERTILITY \& $\quad$ STERILITY $\quad 44, \quad 44-45 \quad$ (2013), available at http://www.asrm.org/uploadedFiles/ASRM_Content/News_and_Publications/Practice_Guidelines/Gui
delines and Minimum Standards/Guidelines_on number_of_embryos\%281\%29.pdf ASRM Transfer Guidelines]; Judith F. Daar, Selective Reduction of Multiple Pregnancy: Lifeboat Ethics in the Womb, 25 U.C. DAVIS L. REV. 773, 777-82 (1992) (describing the procedure as involving the insertion of a needle through the woman's abdomen and into the chest of the fetus to inject potassium chloride in order to stop the fetal heart).
} 
being carried by the intended mother or a gestational surrogate. ${ }^{322}$ It is very unlikely that personhood proponents would treat selective reduction differently than any other procedure that terminates a fetus (or pre-embryo for that matter), ${ }^{323}$ though keeping in mind the exceptions available considering the life and health of the woman experiencing a high-order multiple pregnancy. ${ }^{324}$ Proponents also would be very cognizant of the risk that selective reduction could lead to termination of the entire pregnancy. ${ }^{325}$ Even the American Society of Reproductive Medicine (ASRM) acknowledges that high-order multiple pregnancies should be avoided due to the risks created for the women and fetuses involved. ${ }^{326}$

In fact, Octomom ${ }^{327}$ was identified as a primary reason behind the legislation proposing IVF restrictions in Georgia. ${ }^{328}$ ASRM reported that "in 2000, more than two-thirds of all IVF transfer procedures in the United States were of three or more embryos." ${ }^{329}$ While there are no laws currently governing the number of preembryos that may be transferred in a given IVF cycle in the United States, fertility organizations have offered guidelines calling for a reduced number. ${ }^{330}$ For instance, today ASRM and the Society for Assisted Reproductive Technology (SART) recommend that for women under thirty-five, consideration should be given to implanting only one pre-embryo, and no more than two; though the guidelines still

${ }^{322}$ See Catherine London, Advancing a Surrogate-Focused Model of Gestational Surrogacy Contracts, 18 CARDOzo J.L. \& GENDER 391, 391 (2011) (describing a recent dispute between two Americans-who only wanted one child-and their surrogate stemming from the surrogate's unwillingness to abide by a contract term that would have required her to undergo a selective reduction after she discovered she was carrying twins). It is not my intent to suggest that most selective reductions are sought simply because the intended parents prefer fewer children; only that it can happen.

${ }^{323}$ Cf. Daar, supra note 321, at 796-806; Stacey Pinchuk, A Difficult Choice in a Different Voice: Multiple Birth, Selective Reduction and Abortion, 7 Duke J. GeNDER L. \& POL'Y 29, 34-36 (2000) (each distinguishing selective reduction from abortion by noting, for instance, that in the former the terminated fetuses are not removed from the woman, and the intent is not to end the entire pregnancy). Professor Daar goes as far as to say that this difference with respect to intent "so separates these two procedures as to render them wholly distinguishable." Daar, supra note 322 , at 783 . While personhood proponents may be able to live with a selective reduction when the woman's life is threatened, I am not convinced that they would view the procedure to be so different than abortion as to make it permissible when a patient simply prefers to raise fewer children or even when her health (as opposed to life) is at risk.

${ }^{324}$ See supra notes 129-43 and accompanying text.

${ }^{325}$ Kathleen Lee, In Support of a Gender-Neutral Framework for Resolving Selective Reduction Disputes, 44 FAM. L.Q. 135, 140 (2010) (noting that the risk of terminating the entire pregnancy increases as the number of original fetuses increases).

${ }^{326}$ See ASRM Transfer Guidelines, supra note 321.

${ }^{327}$ When Nadya Suleman underwent IVF in 2008, twelve pre-embryos were transferred-six successfully implanted, with two twinning, resulting in the gestation of eight fetuses. This instance earned her the popular nickname "Octomom." See Alan Duke, Nadya Suleman's Doctor Loses California Medical License, CNN (Jun. 2, 2011), http://articles.cnn.com/2011-0601/us/california.octuplets.doctor.revoked_1_kamrava-fertility-doctor-embryos?_s=PM:US; Lawyer: Octuplets' Mom Implanted with $\overline{1} 2^{-}$Embryos, Associated Press, Oct. 19, 2010 , http://today.msnbc.msn.com/id/39738767/ns/today-today_news/t/lawyer-octuplets-mom-implantedembryos/\#.UDo0KaD2bPg.

${ }^{328}$ See McKay, supra note 275.

${ }^{329}$ ASRM, Elective Single-Embryo Transfer, 97 FERTILITY \& STERILITy 835, 835 (2012), available

http://www.asrm.org/uploadedFiles/ASRM_Content/News_and_Publications/Practice_Guidelines/Co mmittee_Opinions/eSET-nonprintable.pdf [hereinafter ASRM Single-Embryo].

${ }^{330}$ See, e.g., ASRM Transfer Guidelines, supra note 321. 
suggest that it is acceptable for up to five cleavage-stage pre-embryos (two or three days after fertilization) to be implanted in women over forty. ${ }^{331}$

Further, data collected by the CDC suggest that, even in the absence of regulation, in the vast majority of IVF cycles no more than two or three pre-embryos are transferred per cycle, ${ }^{332}$ and ASRM has documented a decrease in triplet gestation. ${ }^{333}$ There is even some evidence to suggest that mandated insurance coverage for IVF could lead to reduced multiple-embryo transfers, because there would be less financial pressure to be successful in fewer attempts. ${ }^{334}$ Nevertheless, if a personhood measure passes, restrictions on the number of pre-embryos that may be transferred in a given cycle are likely to follow to reduce the number of preembryonic persons put at risk. This is particularly true given that some recent studies seem to suggest that increasing the number of pre-embryos transferred does not necessarily increase the likelihood of achieving a successful pregnancy. ${ }^{335}$ After a recent assessment of the literature on single-embryo transfer, ASRM determined that use of the procedure in the United States "has lagged behind that of many other countries," and that "IVF centers should promote [the procedure] when appropriate through provider and patient education.,"336

Perhaps more controversially, the transfer of even a single pre-embryonic person during an IVF cycle could be considered problematic under a personhood framework. ${ }^{337}$ No clinic boasts a $100 \%$ success rate and every failed implantation results in the death of a pre-embryonic person. While the Federal Government does not regulate the practice of IVF, the CDC does collect data from clinics on their success rates. ${ }^{338}$

The CDC breaks down IVF success rates into a number of categories, such as: age of the woman, whether frozen or fresh pre-embryos were transferred (including the number of pre-embryos transferred in a given cycle), and whether donor eggs were used. ${ }^{339}$ Nevertheless, it is difficult to ascertain the precise number of preembryos transferred that survive through birth, because multiple pre-embryos are often transferred, each pre-embryo could itself divide to become a multiple, and the CDC reports multiple-infant births as one live birth. For purposes here the point can be made by noting that in 2010 the CDC reported that only $36.5 \%$ of the fresh, nondonor pre-embryos that were transferred to women under the age of thirty-five actually implanted, with the percentage of implantation decreasing dramatically for

\footnotetext{
${ }^{331}$ ASRM Transfer Guidelines, supra note 321.

${ }^{332}$ See CDC 2010 ART REPORT, supra note 264. Similar data were reported by SART. See Clinic Summary Report, SART (2010), https://www.sartcorsonline.com/rptCSR_PublicMultYear.aspx?ClinicPKID $=0$.

${ }_{333}$ ASRM Single-Embryo, supra note 329 , at 835.

${ }^{334}$ See I. Glenn Cohen \& Daniel L. Chen, Trading-Off Reproductive Technology and Adoption: Does Subsidizing IVF Decrease Adoption Rates and Should it Matter?, 95 MINN. L. REV. 485, 503-04 (2010).

${ }^{335}$ See, e.g., Catherine Pearson, IVF Study Shows 2 Eggs are Good, 3 Too Many, Huffington Post (Jan. 12, 2012), http://www.huffingtonpost.com/2012/01/12/ivf-study-shows-2-eggsar_n_1202020.html (discussing a study in the United Kingdom indicating that implanting three preembryos instead of two does not increase the likelihood of pregnancy); Tiffany Sharples, IVF Study: Two Embryos No Better than One, TIME, Mar. 30, 2009 , http://www.time.com/time/health/article/0,8599,1888299,00.html (identifying a study in Finland suggesting "there is "no advantage to multiple-embryo implantation").

${ }^{336}$ ASRM Single-Embryo, supra note 329, at 839

${ }^{337}$ This issue alone deserves its own article, but it is at least worth mentioning here to highlight discussions that may be had when operating under a personhood framework.

${ }^{338}$ See CDC 2010 ART REPORT, supra note 264.

${ }^{339} \mathrm{Id}$.
} 
women over the age of thirty-five. ${ }^{340}$ Given that not all of these implantations resulted in a live birth (due to miscarriage or stillbirth), we can conservatively say that in 2010 upwards of sixty-five percent of the pre-embryonic persons utilized in IVF in this country died in the process. ${ }^{341}$ Under a personhood framework, one could question whether it is acceptable to knowingly subject these pre-embryonic persons to such a high risk of death.

Admittedly, while this suggests that IVF causes a tremendous loss of preembryonic life, we should keep in mind that when fertilization occurs naturally in the human reproductive process, fifty percent of such fertilized ova are thought to be expelled prior to implantation, and often without the women even knowing fertilization took place. ${ }^{342}$ However, in any given month where a couple has unprotected sex and the woman does not become pregnant, it is impossible to know whether fertilization actually occurred ${ }^{343}$ It would thus be inaccurate to claim that every time a couple has unprotected sex they create a fifty percent chance of killing a pre-embryonic person. ${ }^{344}$ In the context of IVF, however, it is possible to assess the risk to which an existing pre-embryonic person will be exposed by the transfer process. ${ }^{345}$ And according to the CDC, a fresh pre-embryonic person created using a donor egg and transferred into a woman under the age of thirty-five stands a much higher chance of surviving (and being born) than would a fresh pre-embryonic person created from a non-donor egg and transferred to a woman over the age of forty-two. ${ }^{346}$

It is true that the death caused by a failed IVF transfer would not likely be considered intentional (at least using a specific intent definition) under the revised personhood language being proposed, but the inquiry should not end there. ${ }^{347}$ Whether it is acceptable to intentionally create people only to subject them to such a high risk of mortality is an inquiry that would seem necessary when evaluating the ultimate permissibility of IVF under a personhood framework. As discussed in relation to contraception, however, the mere risk of death alone should be insufficient to necessitate a ban on IVF. Rather, at least with respect to yet-to-be created pre-embryonic persons, attention should be paid to whether the risk outweighs the societal benefits, and/or whether certain restrictions could be imposed to bring the level of risk to an acceptable level. ${ }^{348}$ Such restrictions might include limiting the number of pre-embryos that may be created and transferred in a given cycle, or outlawing IVF for individuals with a very low chance of success.

${ }^{340} \mathrm{Id}$. The majority of cycles were performed on women over thirty five, with implantation rates of $26.9 \%$ (ages thirty-five to thirty-seven); $17.7 \%$ (ages thirty-eight to forty); $9.6 \%$ (ages forty-one to forty-two); and $4.2 \%$ (ages forty-three and up). Id. Similar data were reported by SART. See SART Report, supra note 332 .

${ }^{341}$ See CDC 2010 ART REPORT, supra note 264.

${ }^{342}$ Sandel, supra note 150 , at 208.

${ }^{343}$ See discussion supra Part III B and notes 149-50.

${ }^{344}$ See discussion supra Part III B and notes 149-50.

${ }^{345}$ See CDC 2010 ART REPORT, supra note 264.

${ }^{346} \mathrm{Id}$. (indicating that the percentages of transfers resulting in live birth are $55.8 \%$ and $7.4 \%$, respectively). This statistic does not reflect the percentage of pre-embryos that survive through birth, because each transfer will involve multiple pre-embryos, not all of whom will survive even when a transfer results in a live birth.

${ }^{347}$ See supra notes $140,148-50$ and accompanying text.

${ }^{348}$ Military drafts come to mind as a situation where persons are unwillingly subjected to a known and significant risk of death for the greater benefit of society, though there are obvious differences between the two. 
For presently existing pre-embryonic persons (like those in a current state of cryopreservation), the inquiry would likely focus on whether thawing and transfer are in such persons' best interests. ${ }^{349}$ Personhood proponents seek to give preembryonic persons the same legal and moral status as every other born person, and without entertaining any sort of qualitative assessment about the value of such person's life. ${ }^{350}$ By analogy, if we understood that using disposable diapers created a fifty percent chance of newborn death, would we nonetheless allow parents to use disposable diapers? Instead, we might expect a moratorium on disposable diapers, notwithstanding their convenience to parents, until research developed significantly safer disposable diapers.

Parents obviously enjoy substantial constitutional protection to make decisions regarding the upbringing of their children, ${ }^{351}$ but given the children's right to life, "the State, as parens patriae, has a 'wide range of power for limiting parental freedom and authority in things affecting the child's welfare." ${ }^{352}$ In the medical context in particular, courts have struggled to identify the scope of parental decisionmaking authority. ${ }^{353}$ IVF patients could argue that being born, as opposed to remaining in a pre-embryonic state, is in the best interests of the given child, since birth offers the brightest future whereby the child would experience all that life has to offer. They may even argue that this better future is worth the risk of death associated with the IVF process. Indeed, parents make decisions every day that they hope will create the brightest future for their children.

But keeping in mind that under a personhood framework the pre-embryonic person already has full legal and moral status, without reference to qualitative assessments about their life, ${ }^{354}$ the counter argument might look something like this: while it may be true that, as compared to sitting on the couch every day watching Keeping up with the Kardashians, ${ }^{355}$ parents have the best interests of their children in mind when forcing them to attend a four-year college (thereby offering them the best chance of a bright future); if attendance at that school carries with it a fifty percent (or greater) chance of death, would the parents still be justified in forcing their children off the couch? The purpose of this paper is not to resolve this argument, but only to raise it as an illustration of why IVF may be at risk of significant restriction under a personhood framework.

\section{CONCLUSION}

The goal of the Personhood Movement is to create a framework in which human life is extended constitutional protection from the earliest moments of biological development, without exception. ${ }^{356}$ Although personhood proponents may be evasive

\footnotetext{
${ }^{349}$ See supra notes 268-69 and accompanying text.

${ }^{350}$ See supra notes 43-58 and accompanying text.

${ }^{351}$ Troxel v. Granville, 530 U.S. 57, 65-66 (2000).

352 Jonathan F. Will, My God My Choice: The Mature Minor Doctrine and Adolescent Refusal of Life-Saving or Sustaining Medical Treatment Based Upon Religious Beliefs, 22 J. CONT. HEALTH L. \& POL’Y 233, 248 (2006) (quoting Prince v. Massachusetts, 321 U.S. 158, 167 (1944)). making).

${ }^{353} \mathrm{Id}$. at 246-54 (discussing the scope of parental authority in the context of medical decision-

${ }^{354}$ See supra notes 43-58 and accompanying text.

${ }^{355}$ Kim Kardashian's own experience with egg cryopreservation was shared on national television. Abbey Stone, Kim Kardashian Prepares for Motherhood by Freezing Her Eggs, HOLLYWOOD.COM (Sept. 17, 2012), http://www.hollywood.com/news/celebrities/40144952/kimkardashian-prepares-for-motherhood-by-freezing-her-eggs?page=all.

${ }^{356}$ See supra notes 38-41 and accompanying text.
} 
in public debates, if passed, the revised personhood measures being proposed across the country that include this unqualified, biological definition of life, are likely to have significant impacts on reproductive choice. This highlights why it is important to confront what accepting pre-embryonic personhood would mean.

If proponents intend to remain consistent with the personhood position, then any forms of contraception or reproductive technologies that place pre-embryonic persons at significant risk of injury or death become problematic. This is not to say that, from a normative standpoint, all such reproductive choices ought to be banned outright. Rather, to maintain consistency with the position we ought to ask whether such activities create an unacceptable risk of loss of human life, and/or whether such activities are in the best interests of the pre-embryonic persons involved. The purpose of this article has not been to answer those questions; only to create a space for those discussions to be held, and to offer examples of what the restrictions on reproductive choice coming out of those discussions might look like. ${ }^{357}$

\footnotetext{
${ }^{357}$ See supra note 237.
} 


\section{APPENDIX I: PROPOSED COLORADO PERSONHOOD AMENDMENT}

SECTION 32. THE RIGHT TO LIFE.

(1) PURPOSE. In order to affirm basic human dignity, be it resolved that the right to life in this constitution applies equally to all innocent persons.

(2) EFFECT. The intentional killing of any innocent person is prohibited.

(a) Only birth control that kills a person shall be affected by this section.

(b) Only in vitro fertilization and assisted reproduction that kills a person shall be affected by this section.

(c) Medical treatment for life threatening physical conditions intended to preserve life shall not be affected by this section.

(d) Spontaneous miscarriages shall not be affected by this section.

(e) No innocent child created through rape or incest shall be killed for the crime of his or her father.

(3) Definitions. As used in this section,

(a) "Person" applies to every human being regardless of the method of creation.

(b) A "human being" is a member of the species homo sapiens at any stage of development.

(c) "Spontaneous miscarriage" is the unintentional termination of a pregnancy.

(d) "Child" includes a human being prior to and during birth.

(e) "Medical treatment for life threatening physical conditions intended to preserve life" includes but is not limited to treatment for cancer, ectopic and molar pregnancy, twin-to-twin transfusion syndrome, and placenta previa.

(4) Self-eXecuting, AND SEVERABILITy PROVISION. All provisions of this section are self-executing and are severable. ${ }^{358}$

358 Colo. Initiative 46 (2011) (proposed Colo. CONST. art. II, $\S 32$ ), available at http://www.sos.state.co.us/pubs/elections/Initiatives/titleBoard/filings/2011-2012/46Final.pdf. 